\title{
Spatial characterization of the fisheries in the Avilés Canyon System (Cantabrian Sea, Spain)
}

\section{Caracterización espacial de las pesquerías en el Sistema de Cañones de Avilés (mar Cantábrico, España)}

\author{
Antonio Punzón*, Juan Carlos Arronte, Francisco Sánchez, Ana García-Alegre \\ Instituto Español de Oceanografía [Spanish Institute of Oceanography], Promontorio de San Martín SN, \\ 39080 Santander, PO Box 240, Spain. \\ * Corresponding author: antonio.punzon@st.ieo.es
}

\begin{abstract}
Marine protected areas are one of the main tools in ecosystem-based fishery management. This approach requires analyzing the role of fisheries in the ecosystem by, for example, identifying fishing tactics and analyzing the spatial distribution with sufficient precision to allow us to determine whether fishing activities and the habitat or ecosystem to be protected can coexist spatially. In the Avilés Canyon System (Cantabrian Sea, Spain), we detected 6 different gears and 17 fishing tactics were identified by a non-hierarchical classification technique (CLARA). The spatial distribution of demersal fishing activity is strongly affected by the topography of the study area and the large presence of rocky ground. There is a clear spatial segregation between gear types, mainly due to the operating requirements of the gears and the distribution of target species. This minimizes conflicts between different components of the fleet. The fishing tactics targeting pelagic species were mainly located on the coast and shelf, while those targeting demersal species were used on the shelf and slope. Longline fishing tactics are those that had a more restricted spatial distribution.
\end{abstract}

Key words: fisheries, vessel monitoring systems, spatial distribution of fishing effort, Avilés Canyon System, fishing tactics.

RESUMEN. Las áreas marinas protegidas son una de las principales herramientas en la gestión pesquera basada en el ecosistema. Este enfoque requiere evaluar el papel de las pesquerías en el ecosistema mediante, por ejemplo, la identificación de tácticas pesqueras y el análisis de su distribución espacial, y esto permitirá identificar la coexistencia espacial de las actividades pesqueras y los hábitats o ecosistemas objeto de protección. En el Sistema de Cañones de Avilés (mar Cantábrico, España), hemos identificado el uso de 6 artes de pesca y 17 tácticas pesqueras, éstas últimas con una técnica de clasificación no jerárquica (CLARA). La distribución espacial de las actividades pesqueras demersales está fuertemente afectada por la topografía del área de estudio y la gran presencia de sustrato rocoso. Hay una clara segregación espacial entre tipos de artes de pesca, principalmente debido a los requerimientos operativos de las artes de pesca y la distribución de las especies objetivo. Esto minimiza los conflictos entre los distintos componentes de flota. Las tácticas pesqueras dirigidas a especies pelágicas se localizaron principalmente en la zona litoral y en la plataforma continental, mientras que aquellas dirigidas a especies demersales se distribuyeron por la plataforma continental y en el talud continental. Las tácticas pesqueras de palangre de fondo son las que tuvieron una distribución espacial más restringida.

Palabras clave: pesquerías, sistema de seguimiento de buques, distribución espacial del esfuerzo, Sistema de Cañones de Avilés, tácticas pesqueras.

\section{INTRODUCTION}

Fishing activity has important consequences for both the exploited communities and the ecosystems where these activities are conducted. Fishing activity is part of the ecosystem, and its effects are numerous and widely studied (Hollingworth 2000, Cury et al. 2005). Among the most important effects are habitat destruction, mortality of nontarget species, changes in population demographics, and changes in the function and structure of ecosystems (Jennings and Kaiser 1998, Pikitch et al. 2004, Sánchez and Olaso 2004).

This focus has changed the foundations of fisheries management and administration towards what has been called ecosystem-based fishery management (Sinclair et al. 2002,

\section{INTRODUCCIÓN}

La actividad pesquera tiene importantes consecuencias tanto para las comundiades explotadas como para los ecosistemas donde tienen lugar estas actividades. La actividad pesquera es parte del ecosistema, y sus efectos son numerosos y están ampliamente estudiados (Hollingworth 2000, Cury et al. 2005). Entre los efectos más importantes, podemos destacar la destrucción de hábitats, la mortalidad de especies no objetivo, los cambios demográficos en las poblaciones y los cambios en el funcionamiento y estructura del ecosistema (Jennings y Kaiser 1998, Pikitch et al. 2004, Sánchez y Olaso 2004).

Este enfoque ha modificado las bases de la gestión pesquera dirigiéndose hacia lo que se ha llamado gestión 
Link 2005). According to Pikitch et al. (2004), the main objective under this paradigm is to preserve the health of marine ecosystems and the fisheries that depend on them. Accordingly, the concepts of ecosystem approach to fisheries (EAF) and marine protected areas (MPAs, including marine reserves) have been developed as governance and management measures, respectively (Jones 2001, Pauly et al. 2002, Claudet and Pelletier 2004, García and Cochrane 2005). For the implementation of an EAF, it is necessary to obtain a better understanding of how the ecosystem functions (Gislason et al. 2000, Sinclair et al. 2002, Fréon et al. 2005), taking into consideration fisheries as part of the ecosystem and not only as a fishing activity to regulate. In this sense, knowing the behavior of fishing activities, the target species, and the space where they are working are essential aspects for the development of future management plans that minimize the socioeconomic effects on fishing activity and maximize the protection of habitats and target species.

In this context, the countries of the European Union have to create a network of MPAs to ensure the conservation and protection of habitats, resources, and breeding areas, connectivity between areas, etc. Continuous and intensive fishing occurs in many of the MPA candidate sites and any implementation of regulatory measures could bring about large social conflict (Baelde 2005). Therefore, it is essential to gain an understanding of the fishing activity and its relationship with the ecosystem in order to spatially characterize the possible effects on the ecosystems.

The Avilés Canyon System (Fig. 1) is one of 10 areas chosen by the Ministry of Environment in Spain to be designated an MPA and integrated within the European Natura 2000 network. In the area of influence almost all types of fishing gear are used (trawl, longline, purse seine, and gill nets). This makes this area an excellent example of how a structurally and geographically complex zone (GómezBallesteros et al. 2014) is exploited by mixed fisheries.

In the European Union, information on the spatial distribution of fishing activity can be obtained from 2 main sources: logbooks and vessel monitoring systems (VMS). The coupling of VMS and logbook data offers the possibility of performing a precise spatial analysis of fishing activity and its relationship with the affected ecosystems. The present study analyzes and characterizes for the first time the spatial distribution of Spanish fishing activity by fishing tactic (defined as a combination of gear, target species, and working area) in the southern part of the Bay of Biscay. This will allow us to analyze the fishing activity depending on the target species and relate each type of activity to the characteristics of the area. In addition, we can analyze the use of the area made by each gear and fishing tactic and the relationship with the other fishing activities. This information will be one of the main tools for the development of management plans for the Avilés Canyon MPA. pesquera basada en el ecosistema (Sinclair et al. 2002, Link 2005). De acuerdo con Pikitch et al. (2004), el principal objetivo bajo este enfoque es preservar la salud de los ecosistemas marinos y de las pesquerías que dependen de ellos. Por lo tanto, se han desarrollado los conceptos de aproximación ecosistémica a las pesquerías (AEP) y áreas marinas protegidas (AMP, incluidas las reservas marinas), el primero como método de gobernanza y el segundo como herramienta de gestión (Jones 2001, Pauly et al. 2002, Claudet y Pelletier 2004, García y Cochrane 2005). Para la implementación de una AEP, es necesario obtener la mejor comprensión posible del funcionamiento del ecosistema (Gislason et al. 2000, Sinclair et al. 2002, Fréon et al. 2005) teniendo en cuenta a las pesquerías como parte del ecosistema y no sólo como una actividad pesquera a regular. En este sentido, conocer el comportamiento de las actividades pesqueras, sus especies objetivo y la distribución espacial donde trabajan es esencial para el desarrollo de futuros planes de gestión que minimicen los efectos socioeconómicos en la actividad pesquera y maximicen la protección de los hábitats y las especies objetivo.

En este contexto, los países de la Unión Europea deben de crear una red de AMP que asegure la conservación y protección de hábitats, recursos y áreas de cría y reproducción, la conectividad entre áreas, etc. En muchas de las áreas seleccionadas como candidatas a AMP hay una continua e intensiva explotación pesquera y, por lo tanto, cualquier tipo de medida de regulación puede tener como consecuencia importantes conflictos sociales (Baelde 2005). Por consiguiente, es esencial tener conocimiento de la actividad pesquera y su relación con el ecosistema para caracterizar espacialmente los posibles efectos en el ecosistema.

El Sistema de Cañones de Avilés (Fig. 1) es una de las 10 áreas elegidas por el Ministerio de Medio Ambiente en España a ser designadas AMP e integradas dentro de la red Europea Natura 2000. En su área de influencia, son utilizadas casi todos los tipos de arte de pesca (arrastre, palangre, cerco y enmalle). Esto hace de esta área un excelente ejemplo de cómo una zona estructural y geográficamente compleja (Gómez-Ballesteros et al. 2014) es explotada por pesquerías mixtas.

En la Unión Europea, la información de la distribución espacial de la actividad pesquera se puede obtener de 2 fuentes: cuadernos de pesca y datos de sistemas de seguimiento de buques (SSB). El acoplamiento de los datos de los SSB y cuadernos de pesca ofrece la posibilidad de obtener un análisis espacial preciso de la actividad pesquera y su relación con los ecosistemas afectados. Este estudio analiza y caracteriza por primera vez la actividad espacial de las pesquerías españolas por táctica pesquera (definida como una combinación de arte de pesca, especie objetivo y área de trabajo) en el sur del golfo de Vizcaya (España). Esto nos permitirá analizar la actividad pesquera según la especie objetivo y relacionar cada tipo de actividad a las características del área. Además podremos analizar el uso que hacen 


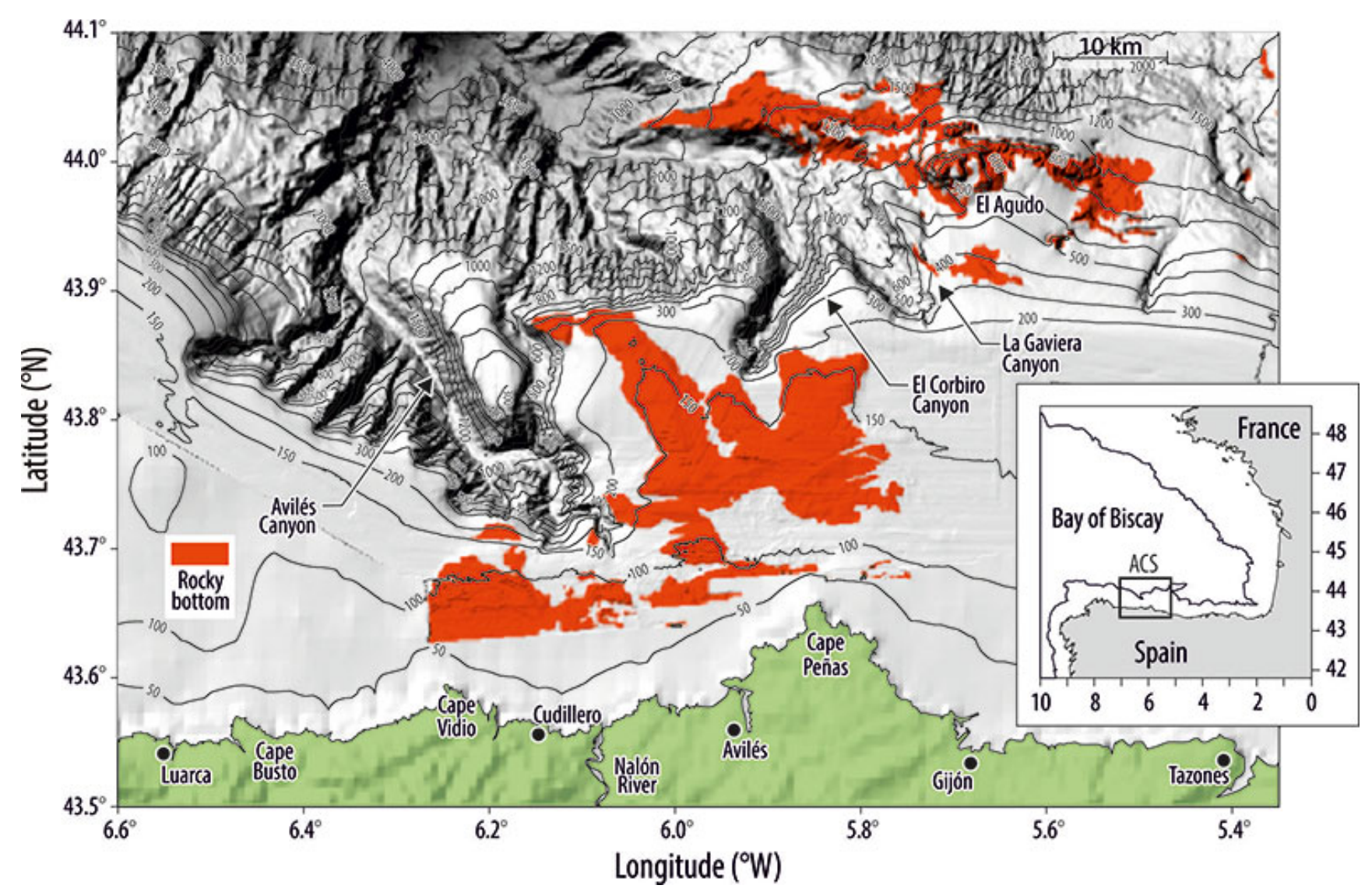

Figure 1. Study area (ACS, Avilés Canyon System).

Figura 1. Área de estudio (ACS, Sistema de Cañones de Avilés).

\section{MATERIALS AND METHODS}

\section{Study area}

The study area is located in the Cantabrian Sea (southern Bay of Biscay) and consequently falls within OSPAR Region IV. This whole area is characterized by a narrow platform and by deep-sea canyons. The Avilés Canyon System (Fig. 1) is a complex region of canyons and valleys comprising 3 main canyons of different morphostructural characteristics (Gómez-Ballesteros et al. 2014). The near continental shelf is generally narrow; the width varies from $12 \mathrm{~km}$ (where the head of the Avilés Canyon is incised) to $40 \mathrm{~km}$. Maximum depths are approximately $200 \mathrm{~m}$, but occasionally reach $300 \mathrm{~m}$ east of the canyon. The continental shelf displays rocky outcrops of different reliefs and morphologies, and a nearly horizontal surface corresponding to sedimentary areas with unconsolidated sediment cover or heavily eroded basement surfaces. The strong currents over the shelf are responsible for the minimal sedimentary cover in the area.

\section{Data source}

The bathymetric information presented here was obtained during two surveys carried out aboard the R/V Vizconde de del área cada tipo de arte y táctica pesquera y su relación con las otras actividades pesqueras. Esta información deberá ser una de las herramientas principales para el desarrollo de los futuros planes de gestión, como el del AMP del Cañón de Avilés.

\section{MATERIALES Y MÉTODOS}

\section{Área de estudio}

El área de estudio está localizada en el mar Cantábrico (sur del golfo de Vizcaya) y, por lo tanto, dentro de la Región IV de OSPAR. Toda la zona se caracteriza por una plataforma continental estrecha y cañones submarinos profundos. El Sistema de Cañones de Avilés (Fig. 1) es una región compleja de cañones y valles formada principalmente por 3 cañones de diferentes características morfoestructurales (Gómez-Ballesteros et al. 2014). La plataforma continental cercana es generalmente estrecha; el ancho varía de $12 \mathrm{~km}$ (en la cabecera del Cañón de Avilés) a 40 km. Las profundidades máximas son de unos $200 \mathrm{~m}$ y ocasionalmente hasta de $300 \mathrm{~m}$ al este del cañón. La plataforma continental muestra afloramientos rocosos de diferentes relieves y morfologías, y una superficie casi horizontal que corresponde a las zonas 
Eza between 2010 and 2011 using a Simrad EM-300 multibeam echosounder (Gómez-Ballesteros et al. 2014).

The spatial distribution of the activities of the industrial fleet was analyzed using logbook and VMS information. The logbook information corresponded to the period 2002-2010 for the entire Cantabrian Sea (southern Bay of Biscay), and it was used to identify the fishing gear and fishing tactics (Marchal et al. 2006). The VMS information covered the period 2006-2010, and only the data corresponding to the study area were used. VMS data were also used to carry out the spatial analysis of the fishing tactics previously identified in the logbooks. The VMS and logbook data were provided by the Spanish Ministry of Agriculture, Food and Environment (MAGRAMA, for its initials in Spanish).

A VMS is a tracking device that sends a signal (ping) every $2 \mathrm{~h}$ that contains the code of the emitting ship, date, time, position (latitude and longitude), speed in knots, course, and whether the vessel is carrying out fishing operations or not. Many filters and processing techniques are used to eliminate signals not related to fishing activity (Lee et al. 2010, Hintzen et al. 2011). In this study, the following processing technique was used: the time interval and the Euclidean distance between successive signals were obtained, and each of these values was associated with the first signal of each corresponding pair; when the time interval between signals was longer than $4 \mathrm{~h}$, the beginning and end of each fishing expedition was determined; the average speed of the vessel was calculated using the interval between successive signals (pings); vessels with less than 10 signals in a year were eliminated; signals recorded within a distance of 3 miles or less from the closest fishing harbor were also eliminated. Each signal coinciding with a fishing trip registered in the logbooks (according to the vessel code and the date of capture) was associated with a fishing gear and a fishing tactic. Based on the distribution of the frequencies of average speeds, a working range for each fishing gear was defined, and all signals with associated velocities out of the working range were eliminated (Hintzen et al. 2011). For the study area, 51.6\% of 46,075 VMS fishing days could be matched with their logbook records for the period 2006-2010 and both fishing gear and fishing tactic could be assigned to each matched day.

The frequency distribution of the average velocities was used to determine the average speed ranges at which we considered fishing activity to be carried out (Fig. S1). The identification of these ranges can be achieved by either locating changes in the tendency through the use of regression models (segmented regression) or using available information from the fleet and on-board observers. In the case of mobile fisheries (trawling and handline trawling), both methods are used, whereas in the case of static fisheries (purse seine, gillnet, longline, and handline fishing), it is better to use the information provided by on-board observers and the information obtained from the fleet according to the frequency distribution. The speed ranges by fishing gear can be seen in Table 1. sedimentarias con cobertura de sedimentos no consolidados o superficies fuertemente erosionadas. Las fuertes corrientes sobre la plataforma continental son responsables del mínimo recubrimiento sedimentario en el área.

\section{Fuentes de datos}

La información de la batimetría se obtuvo durante 2 campañas llevadas a cabo en el B/I Vizconde de Eza entre 2010 y 2011 utilizando la ecosonda multihaz Simrad EM-300 (Gómez-Ballesteros et al. 2014).

La distribución espacial del esfuerzo de la flota industrial fue analizada utilizando la información de los cuadernos de pesca y de los SSB. La información de los cuadernos de pesca correspondió al periodo 2002-2010 para todo el mar Cantábrico (sur del golfo de Vizcaya), y fue utilizada para la identificación de artes de pesca y tácticas pesqueras (Marchal et al. 2006). La información de los SSB correspondió al periodo 2006-2010, y únicamente se usaron los datos correspondientes a la zona de estudio. Estos datos se utilizaron para el análisis espacial de las tácticas pesqueras identificadas previamente mediante los cuadernos de pesca. La información del SSB y los cuadernos de pesca fue facilitada por el Ministerio de Agricultura, Alimentacíon y Medioambiente (MAGRAMA) de España.

Respecto a los SSB, el dispositivo de localización envía cada $2 \mathrm{~h}$ una señal (ping) que registra el código del barco emisor, la fecha, la hora, la posición (latitud y longitud), la velocidad en nudos, el rumbo y si el barco está realizando operaciones de pesca o no. Se han aplicado muchos filtros y tipos de procesado para eliminar aquellas señales no asociadas a la actividad pesquera (Lee et al. 2010, Hintzen et al. 2011). En este estudio se utilizó el siguiente procesado: se obtuvó el intervalo de tiempo y la distancia euclidiana entre señales sucesivas, y cada uno de estos valores fue asociado a la primera señal del correspondiente par de puntos; se identificó el comienzo y la finalización de las mareas de pesca, cuando el tiempo transcurrido entre señales sucesivas fue más de 4 h; se calculó la velocidad media de la embarcación entre señales (pings) sucesivas; se eliminaron todas aquellas embarcaciones para las cuales hubiera menos de 10 señales a lo largo de un año; y se eliminaron todas aquellas señales que estaban a menos de 3 millas del puerto pesquero más cercano. A cada señal que coincidía con una marea de los cuadernos de pesca (en función del código del buque y la fecha de captura) se le asignó un arte de pesca y una táctica pesquera. En función de la distribución de frecuencias de velocidades medias, se definió un rango de velocidades de trabajo para cada arte de pesca y todas aquellas señales con velocidades fuera de rango se eliminaron (Hintzen et al. 2011). Para la zona de estudio, al $51.6 \%$ de los 46,075 días de pesca procedentes de los SSB se les pudo asignar un arte de pesca y una táctica pesquera a partir de la información de los cuadernos de pesca para el periodo entre 2006 y 2010. 
Table 1. Speed range $(\mathrm{nm})$ by gear when it was considered that there was fishing.

Tabla 1. Rango de velocidades (nm) por arte de pesca en el que se consideraba que se estaba pescando.

\begin{tabular}{lcc}
\hline Gear & Minimum & Maximum \\
\hline Bottom otter trawl (OTB) & 2.2 & 4.2 \\
Bottom pair trawl (PTB) & 1.4 & 2.3 \\
Set longline (LLS) & 0.1 & 1.5 \\
Set gillnet (GNS) & 0.1 & 1.5 \\
Handline (HLM) & 0.1 & 2.2 \\
Purse seine (PS) & 0.1 & 2.2 \\
\hline
\end{tabular}

On wide continental shelves with sedimentary bottoms such as in the North Sea, the fishing areas are generally extensive. In these cases, after filtering and analyzing VMS data, the distribution of fishing efforts can clearly be observed. Therefore, areas containing points with no fishing activity are scarce (Hintzen et al. 2011). However, fishing areas located on narrow continental shelves with rocky mosaic bottoms or on continental slopes are generally narrow and short. In these cases, it is frequent to find areas where fishing activity is apparently being carried out when, in reality, there is no activity. To eliminate false fishing activity, it is necessary to apply thresholds to define when fishing activity is actually carried out.

Thresholds were applied to determine if the filtered VMS data corresponded to real fishing activity. Thus, the effort value was assigned to each corresponding point where fishing was detected (see "Estimation of relative spatial effort" section below). Subsequently, it was necessary to set a threshold for the effort value below which fishing activity was considered to be negligible or non-existent, for which there are numerous techniques (Jiménez-Valverde and Lobo 2007). The techniques that provided the best outcomes were based on applying quartile thresholds. Points at which the presence of fishing was detected were eliminated according to the distribution of the effort frequencies (Fig. 2). The use of other statistics based on generating pseudo-absences to distinguish points with real presence was not fruitful because efforts were located in specific places. Thus, when generating pseudo-absences and eliminating those that corresponded to real activity locations, pseudo-absences always occurred over zones where there was no activity; consequently, the threshold values were so low that we could not distinguish between real and false presences. Thresholds can be applied to fishing tactics or to fishing gear. If the relative importance of thresholds is small, it is better to apply them to fishing tactics; otherwise, it is more effective to apply them to fishing gear. In our case, comparing the distribution of effort with the distribution of pings (Fig. 2), when a 0.2 threshold was applied all those points that were outside the fishing area were
Para determinar los rangos de velocidades en los que se consideraba que había actividad pesquera, se utilizó la distribución de frecuencias de velocidades medias (Fig. S1). La identificación de rangos de velocidades de trabajo se puede hacer bien identificando los cambios de tendencia mediante modelos de regresión (regresión segmentada) o utilizando la información proporcionada por la flota y los observadores a bordo. Para las pesquerías móviles (arrastre y líneas de manos al arrastre), se utilizan ambos métodos de forma combinada, mientras que para las pesquerías estáticas (pesca con cerco, enmalle, palangre y línea de mano estática), es mejor usar la información de observadores a bordo y la procedente de la flota en función de la distribución de frecuencias. Los rangos de velocidades empleados en el trabajo por arte de pesca pueden verse en la Tabla 1.

En las plataformas continentales anchas con fondo sedimentario, como en el mar del Norte, las áreas de pesca generalmente son muy amplias. En estos casos, después de aplicar los filtros y analizar los datos del SSB, la distribución del esfuerzo de pesca puede ser observada claramente. Por lo tanto, son escasas las áreas con puntos que no corresponden a actividad pesquera. Sin embargo, las áreas de pesca sobre plataformas continentales estrechas con fondos rocosos distribuidos en mosaico o en el talud continental son generalmente angostas y cortas. En estos casos, es frecuente encontrar áreas donde aparentemente existe actividad pesquera, cuando en realidad no existe tal actividad. Para eliminar actividad pesquera falsa, es necesario aplicar umbrales para definir cuándo realmente existe actividad pesquera.

Se aplicaron umbrales para detectar si, una vez filtrados los datos procedentes de los SSB, los puntos correspondían realmente a actividad pesquera. A cada ping se le asignó el valor de esfuerzo que le correspondía (ver sección "Estimación de la distribución espacial del esfuerzo relativo"). Posteriormente, se aplicó el umbral de esfuerzo por debajo del cual se considera que la actividad no existe o es despreciable. Existen múltiples técnicas para definir este umbral (JiménezValverde y Lobo 2007). Las que ofrecieron mejor resultado fueron las de aplicar umbrales en base a cuartiles. Se eliminaron puntos de presencia de actividad de pesca de acuerdo con la distribución de las frecuencias del esfuerzo (Fig. 2). La aplicación de otros estadísticos, basados en generar pseudoausencias para realizar la discriminación de puntos de presencia verdaderos, no fue fructífera. Esto se debe a que el esfuerzo se concentró en sitios específicos y, por lo tanto, al generar pseudoausencias y eliminar todas aquellas que coinciden con puntos reales de presencia, las pseudoausencias solamente cayeron en zonas donde realmente hubo ausencia de actividad; consecuentemente, los umbrales fueron tan bajos que no fue posible discriminar entre presencias reales y falsas. Los umbrales se pueden aplicar por arte de pesca o táctica pesquera. Si la importancia relativa del umbral es baja, es mejor aplicar los umbrales por táctica pesquera; en cualquier otro caso, es más efectivo aplicarlo por arte de 


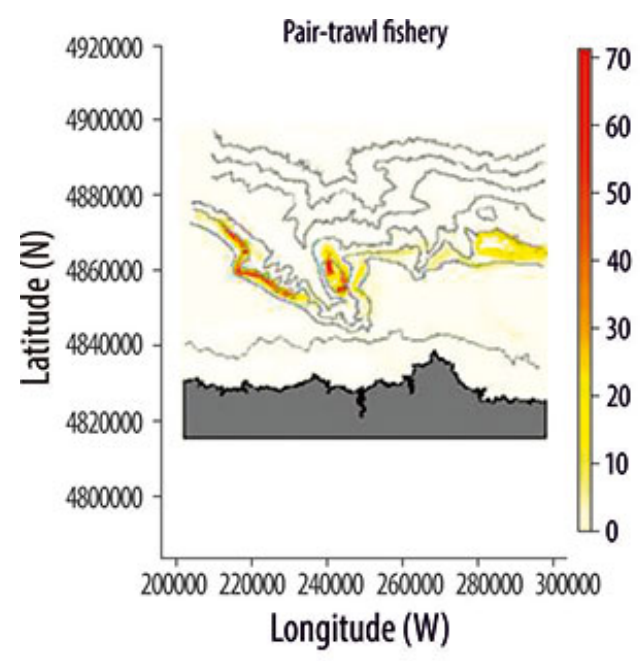

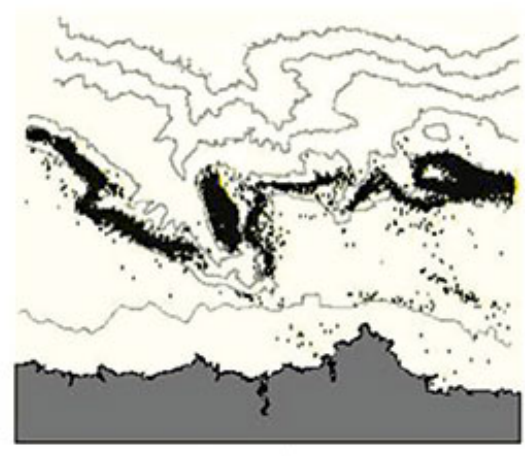

Percentile: 0.10

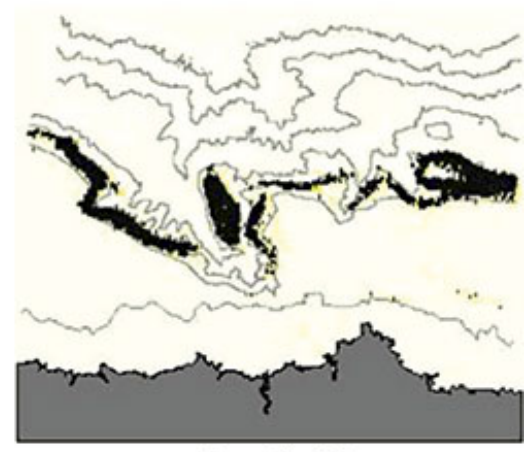

Percentile: 0.20

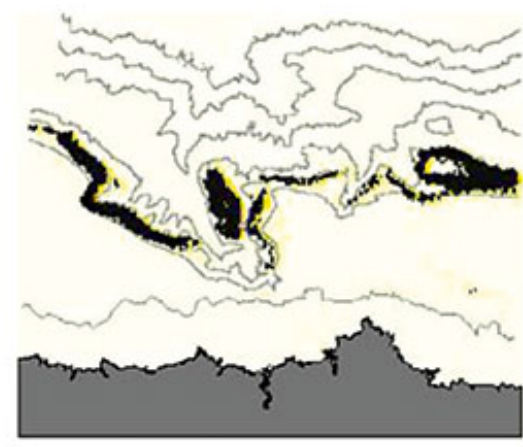

Percentile: 0.25

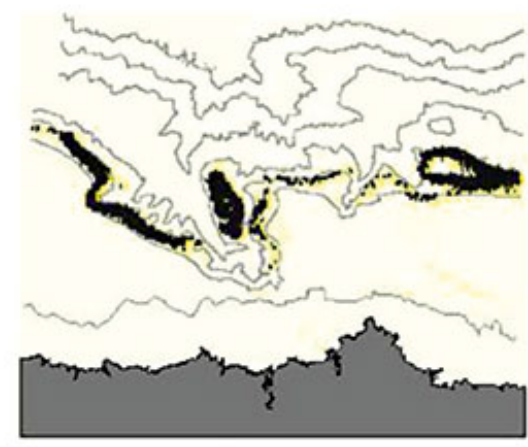

Percentile: 0.30

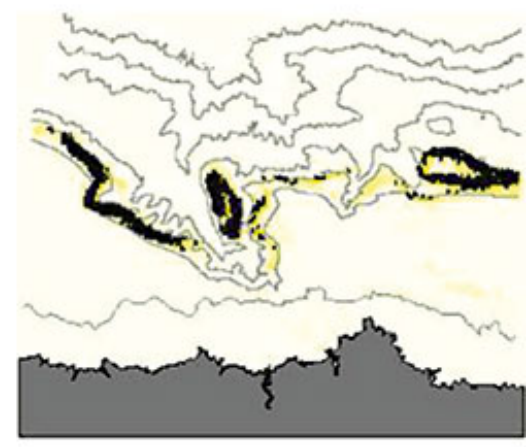

Percentile: 0.40

Figure 2. Threshold selection for the pair trawl fishery.

Figura 2. Selección de umbrales para la pesquería de arrastre de fondo a la pareja.

eliminated without affecting the estimation of the effort of the main fishing areas. After inspecting the spatial distribution of the effort of all fishing gears the threshold was applied to all.

\section{Identification of fishing tactics}

The terminology used in the present study was defined in ICES (2003) and used by Marchal et al. (2006): fleet, a group of vessels with similar characteristics, and fishing tactic, trips made targeting the same species/stock or a combination of these using similar gear in the same period of the year and in the same area. The identification of fishing techniques was performed by gear. To standardize the landings by trip for each of the gears, the species composition of each trip was expressed as a percentage of the total amount caught (Jiménez et al. 2004, Campos et al. 2007). Those species representing less than $1 \%$ of the total landings were incorporated into the matrix in a group called "other". Given the doubtful classification of deep-sea sharks conducted on board, this taxonomic group was separated into 2 categories: deep-sea sharks and other sharks, which included all remaining sharks. pesca. En nuestro caso, al comparar la distribución del esfuerzo con la distribución de pings (Fig. 2), se observó que cuando se aplicó un umbral de 0.2 , todos aquellos puntos que estaban fuera de las áreas de pesca fueron eliminados sin afectar la estimación del esfuerzo en las principales áreas de actividad pesquera. Después de evaluar la distribución espacial del esfuerzo para todas las artes de pesca, se aplicó el mismo umbral para todas ellas.

\section{Identificación de tácticas pesqueras}

La terminología utilizada en el presente trabajo fue definida por ICES (2003) y usada por Marchal et al. (2006): flota, grupo de barcos con similares características, y táctica pesquera, grupo de mareas dirigidas a la misma especie, población pesquera o una combinación de éstas usando un arte de pesca similar en el mismo periodo del año y en la misma área. La identificación de tácticas pesqueras fue hecha por arte de pesca. Para estandarizar las capturas por marea para cada una de las artes de pesca, la composición específica de cada una de las mareas se expresó en porcentaje respecto al total de la captura de la marea (Jiménez et al. 2004, Campos 
The non-hierarchical cluster technique CLARA (Clustering Large Applications, Kaufman and Rousseeuw 1986) was used to identify and classify fishing tactic by fishing gear. The silhouette width (Rousseeuw 1987) was used to select the number of clusters, and to validate the consistency of the clustering we followed the criteria of Struyf et al. (1996), in which 4 levels are defined for the global silhouette coefficient and partial silhouette coefficient: 0.71-1.00, consistent pattern; 0.51-0.70, reasonable pattern; 0.26-0.50, weak pattern; <0.26, no pattern. A detailed explanation of the use of this technique in fisheries can be found in Castro et al. (2010).

The analyses were performed using $\mathrm{R}$ ( $\mathrm{R}$ Development Core Team 2005). The correspondence and principal component analyses were performed using the "ade4" library (Dray and Dufour 2007), and the cluster analyses were performed with the "cluster" (Maechler et al. 2005) and "stats" (R Development Core Team 2005) libraries.

\section{Estimation of relative spatial effort}

The spatial effort was estimated using a grid spacing of $250 \mathrm{~m}$. Thus, a 250-m search radius was chosen in each node such that adding up the time assigned to each ping emitted by the VMS corresponded to the presence detected within each radius. By taking a radius whose length was the same as the grid spacing, we achieved better geographic precision of effort, overestimating those locations where presence was more frequent.

\section{Estimation of overlap between demersal fisheries}

The overlap between demersal fishing gears was analyzed: bottom otter trawl (OTB), bottom pair trawl (PTB), set gillnet (GNS), and set longline (LLS). When analyzing the overlap between fishing activities, it is necessary to take into account that the VMS indicates the position of the boat, not the position of fishing gear. In order to avoid false positives or false negatives, values greater than $20 \%$ with respect to the maximum value of effort were taken into account and the resolution of layers was lowered to $1,000 \mathrm{~m}$. To analyze the overlap, each pixel with activity of the layers analyzed was given the value 1 , and the layers with the fishing techniques analyzed were added (PTB vs OTB, GNS vs LLS, and set gear vs mobile gear). The result was a final raster layer with the following values: NA, absence of activity; 1 , activity of one of the 2 fishing techniques analyzed; and 2, overlap of the activity.

\section{RESUlts}

\section{Fishing tactics in the study area}

All of the fishing gears were present in the study area: OTB, PTB, GNS, LLS, purse seine (PS), and handline et al. 2007). Aquellas especies que representaron menos del $1 \%$ del total de las capturas se agruparon en la matriz bajo la denominación “otros”. Dado que existen dudas de la clasificación de los tiburones de profundidad ya a bordo, este grupo taxonómico fue separado en 2 categorías: tiburones de profundidad y otros tiburones, que incluye el resto de los tiburones.

Con el objeto de identificar las tácticas pesqueras por arte de pesca, se realizó una agrupación no jerárquica denominada CLARA (Agrupación para Grandes Matrices, Kaufman y Rousseeuw 1986). Se utilizó el ancho de silueta (Rousseeuw 1987) para seleccionar el número de agrupaciones, y para validar la consistencia de la clasificación de la agrupación, se siguió el criterio de Struyf et al. (1996), en el cual se definen 4 niveles para el coeficiente global de silueta y para el coeficiente parcial de silueta: 0.71-1.00, estructura consistente; 0.51-0.70, estructura razonable; 0.26-0.50, estructura débil; <0.26, no existe un patrón. Una explicación detallada del uso de esta técnica en pesquerías puede verse en Castro et al. (2010).

Los análisis se realizaron con $\mathrm{R}$ ( $\mathrm{R}$ Development Core Team 2005). Los análisis de componentes principales y de correspondencias se realizaron con la paquetería “ade4” y el análisis de agrupación se realizó con las paqueterías "cluster” (Maechler et al. 2005) y “stats” (R Development Core Team 2005).

\section{Estimación de la distribución espacial del esfuerzo relativo}

La distribución espacial del esfuerzo se estimó usando una rejilla de $250 \mathrm{~m}$. A cada nodo se le aplicó un radio de búsqueda de $250 \mathrm{~m}$ y se sumó el tiempo asignado a cada ping de presencia que estaba dentro de cada radio. El asignar un radio igual al tamaño de la rejilla permite mejorar la precisión geográfica del esfuerzo, sobreestimando aquellas zonas donde existe mayor número de pings.

\section{Estimación del solapamiento entre artes de pesca demersales}

Se analizó el solapamiento entre las artes de pesca demersales: arrastre de fondo con puertas (OTB), arrastre de fondo a la pareja (PTB), enmalle fijo (GNS) y palangre de fondo fijo (LLS). A la hora de analizar el solapamiento entre actividades pesqueras, hay que tener en cuenta que el SSB indica la posición del barco, no la posición del arte de pesca. Con el objeto de evitar falsos positivos o falsos negativos, se tuvieron en cuenta valores mayores que el $20 \%$ respecto al valor máximo del esfuerzo, y la resolución de la capa fue rebajada a 1,000 m. Para analizar el solapamiento, a cada pixel con actividad de las capas analizadas se le asignó el valor 1 , y se sumaron las capas de las artes de pesca a analizar (PTB vs OTB, GNS vs LLS, y artes de pesca fijos vs artes de pesca móviles). El resultado final fue una capa ráster con los 
(HLM). Longline targeting Dicentrarchus labrax (sea bass) and purse seine targeting Engraulis encrasicolus (anchovy) were not considered in the present study because they were poorly represented in the study area (3 and 6 fishing trips, respectively). The global silhouette coefficient by fishing gears showed values equal to or greater than 0.5 ; hence, all of the classifications could be considered robust (Table 2). A total of 17 fishing tactics were identified. For all fishing tactics the target species appear in $100 \%$ of the trips (frequency of occurrence, FO), except for mixed otter trawl (OTB_MIX), purse seine targeting Trachurus spp. (PS_HOM), and handline targeting tuna (HLM_TUN).

Three otter trawl fishing tactics were identified. The first was a mixed fishing tactic (OTB_MIX) targeting several demersal species, none of them accounting for more than $17 \%$ of the landings and almost $45 \%$ of the landings corresponding to 3 species (Lophius spp., monkfish; Lepidorhombus spp., megrims; and Merluccius merluccius, hake); the main species in FO were Lophius spp. The second tactic targeted Trachurus trachurus (horse mackerel) (OTB_HOM), which accounted for $80 \%$ of the landings, with some demersal species as bycatch. The third tactic (OTB_MAC) targeted Scomber spp. (mackerel), with Trachurus spp. as bycatch (FO = 43). Regarding pair trawling, only 2 fishing tactics were identified, the first targeting Micromesistius poutassou (blue whiting) (PTB_WHB), with Merluccius merluccius (hake) as the main non-targeted species $(\mathrm{FO}=80)$, and the second targeting Scomber spp. (PTB_MAC) and blue whiting as main bycatch $(\mathrm{FO}=43)$.

Four longline fishing tactics were identified. One tactic targeted Conger conger (conger) (LLS_COE) and another targeted Phycis blennoides (greater forkbeard) (LLS_GFB), the former capturing $P$. blennoides as bycatch and the latter capturing $C$. conger as bycatch. A third tactic targeted hake (LLS_HKE), without any significant bycatch, and a fourth targeted Pollachius spp. (LLS_POL) with sparids as bycatch, which were unloaded during $58 \%$ of fishing trips (FO), thus accounting for only $7.81 \%$ of the landings by weight. In the case of all fishing tactics, bycatches were of little importance compared with the target species both in quantity and frequency.

Three gillnet fishing tactics were identified. The first tactic targeted hake (GNS_HKE) and the second targeted Lophius spp. (monkfish) (GNS_MNZ), without any characteristic bycatch species. The third targeted species from the "other" group (GNS_MIX), with hake and monkfish as bycatch species.

In the area of influence of the Avilés Canyon System, purse seines and handlines are used to catch pelagic species. In the case of the purse seine net, 3 different fishing tactics were observed: the first targeted horse mackerel (PS_HOM), with Boops boops $(\mathrm{FO}=17)$ and Sardina pilchardus $(\mathrm{FO}=$ 29) as main bycatch species; the second targeted mackerel (PS_MAC); and the third targeted Sardina pilchardus (sardine) (PS_PIL), with horse mackerel $(\mathrm{FO}=19)$ and mackerel siguientes valores: NA, ausencia de la actividad; 1 , actividad de uno de los 2 tipos de artes analizados; y 2, solapamiento de la actividad.

\section{RESUltados}

\section{Tácticas pesqueras en el área de estudio}

Todas las artes de pesca (OTB, PTB, GNS, LLS, cerco [PS] y línea de mano [HLM]), estuvieron presentes en el área de estudio. El palangre de fondo dirigido a Dicentrarchus labrax (lubina) y el cerco dirigido a Engraulis encrasicolus (anchoa) no se tuvieron en cuenta en el presente estudio porque estuvieron pobremente representados (3 y 6 mareas de pesca, respectivamente). Los valores del coeficiente global de silueta por arte de pesca fueron iguales o mayores que 0.5 ; por lo tanto, todas las clasificaciones podrían ser consideradas robustas (Tabla 2). Se identificaron 17 tácticas pesqueras. En todas las tácticas pesqueras la especie objetivo aparece en el $100 \%$ de las mareas de pesca (frecuencia de ocurrencia, FO), excepto en el arrastre con puertas mixto (OTB_MIX), el cerco dirigido a Trachurus spp. (PS_HOM) y la línea de mano dirigida a túnidos (HLM_TUN).

Se identificaron 3 tácticas pesqueras con arrastre de fondo con puertas. La pimera fue una táctica mixta (OTB_MIX) dirigida a varias especies demersales, ninguna de las cuales superó el $17 \%$ de los desembarques y casi el $45 \%$ de los desembarques correspondió a 3 especies (Lophius spp., rapes; Lepidorhombus spp., gallos; y Merluccius merluccius, merluza); las especies más importantes en FO fueron Lophius spp. La segunda táctica pesquera fue dirigida a Trachurus spp. (jurel) (OTB_HOM), el cual supone el 80\% de las capturas, con alguna especie demersal como captura accesoria. La tercera táctica fue dirigida a Scomber spp. (caballa) (OTB_MAC), y Trachurus spp. fue captura accesoria (FO = 43). En el caso del arrastre a la pareja, se identificaron 2 tácticas pesqueras, la primera dirigida a Micromesistius poutassou (lirio) (PTB_WHB) con Merluccius merluccius (merluza) como principal especie no objetivo $(\mathrm{FO}=80)$ y la segunda dirigida a Scomber spp. (PTB_MAC) con lirio como principal especie accesoria $(\mathrm{FO}=43)$.

Se identificaron 4 tácticas pesqueras con palangre de fondo fijo. Una táctica fue dirigida a Conger conger (congrio) (LLS_COE) y otra a Phycis blennoides (locha) (LLS_GFB), y cada una de estas especies fue la principal especie accesoria de la otra táctica. La tercer táctica fue dirigida a merluza (LLS_HKE), sin que hubiera ninguna otra especie accesoria relevante, y la cuarta fue dirigida a Pollachius spp. (LLS_POL) con los espáridos como principales especies accesorias, las cuales fueron descargadas en el $58 \%$ de las mareas de pesca (FO) y compusieron sólo el $7.81 \%$ de las capturas en peso. En todas las tácticas pesqueras, las especies accesorias tuvieron poca importancia en comparación con las especies objetivo, tanto en FO como en peso. 
Table 2. Catch profile expressed as percent of total weight and frequency of occurrence (FO) by gear (GCS, global silhouette coefficient) and fishing tactic (PCS, partial silhouette coefficient). Only the species that comprised more than $1 \%$ of the catch are shown.

Tabla 2. Composición de la captura expresada en porcentaje de peso total y frecuencia de ocurrencia (FO) por arte de pesca (GCS, coeficiente global de silueta) y táctica pesquera (PCS, coeficiente parcial de silueta). Sólo se muestran las especies que superaron el $1 \%$ de la descarga.

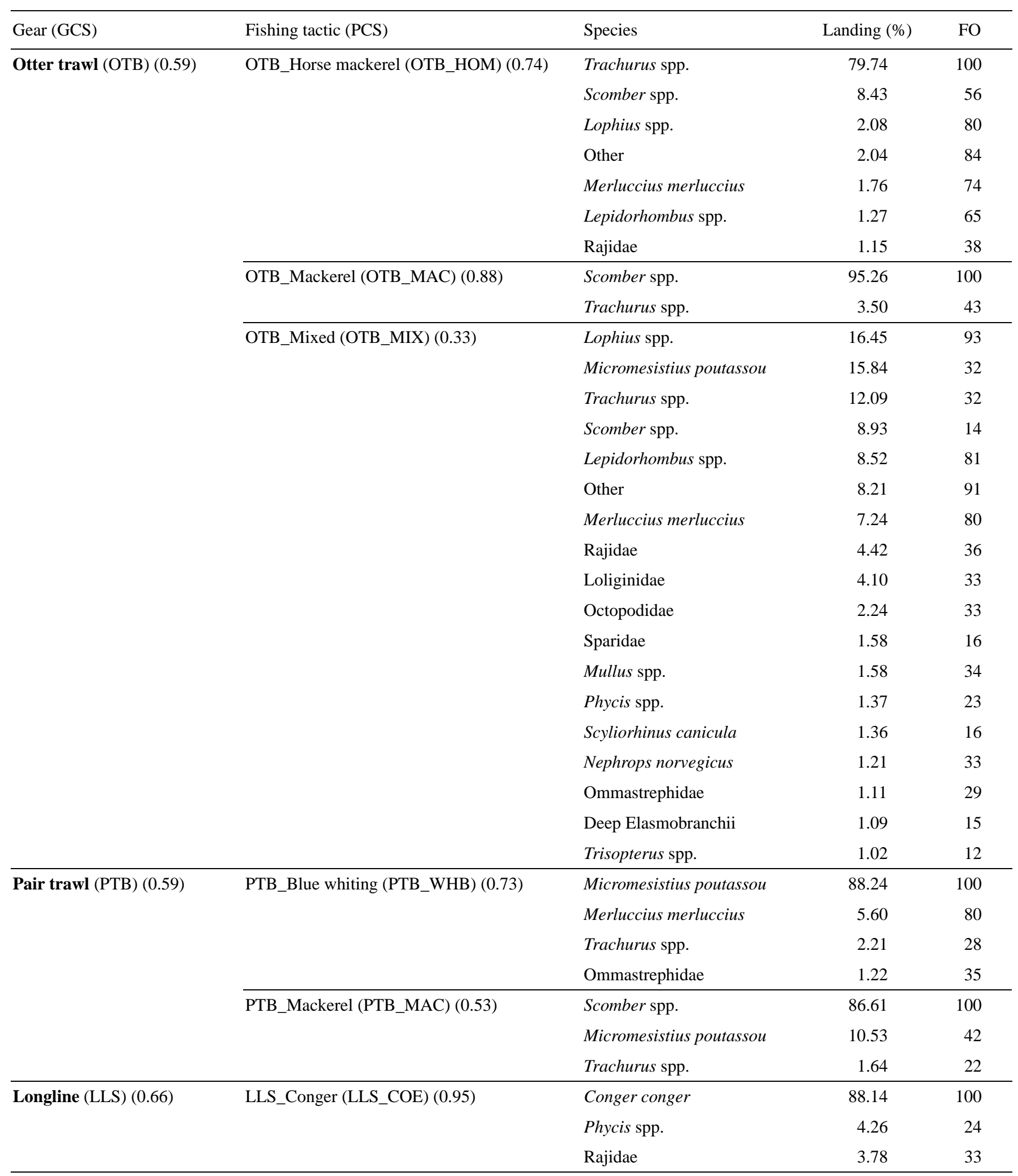


Table 2 (Cont.)

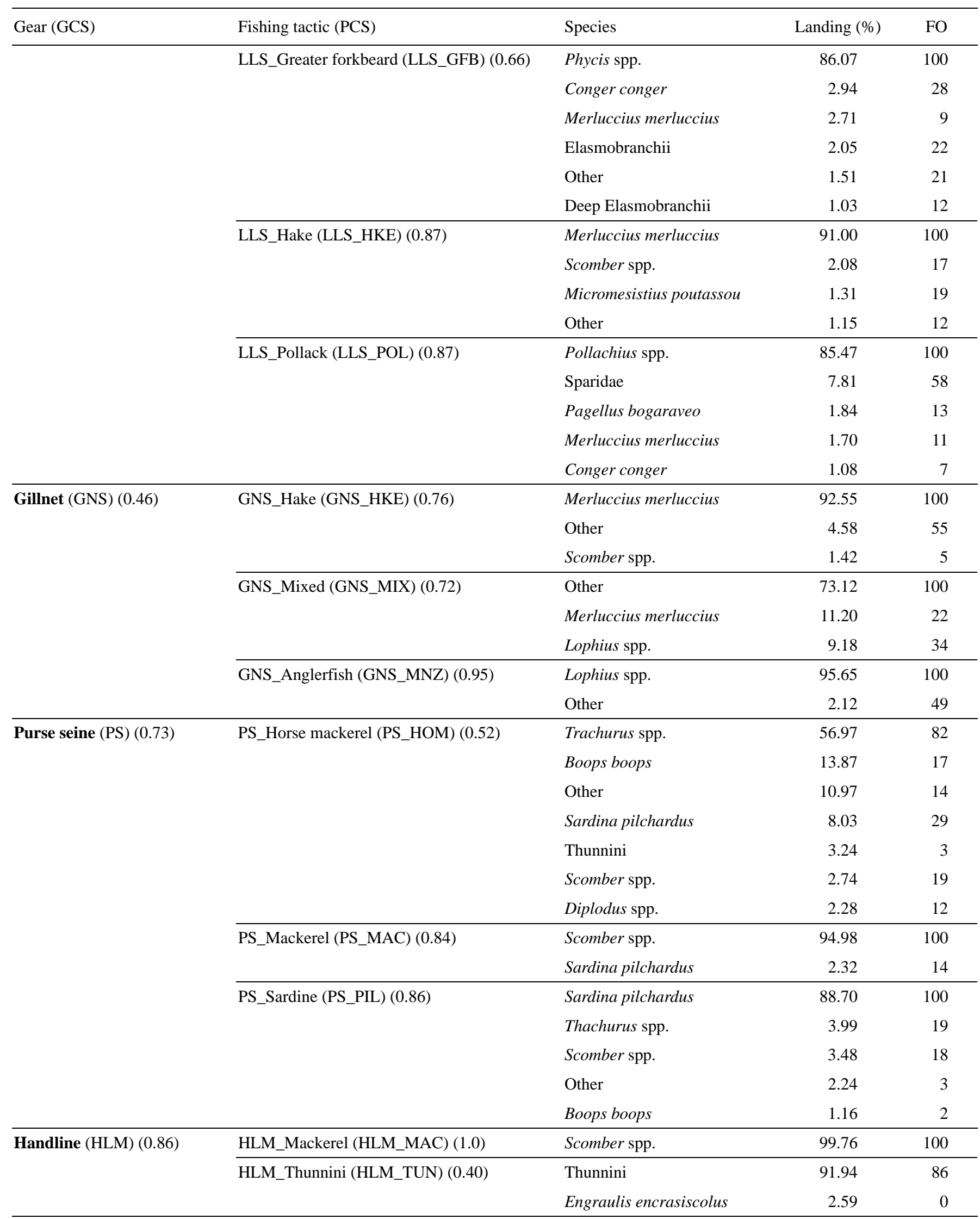


(FO = 18) as bycatch. Finally, 2 handline fishing tactics were identified, one targeting mackerel (HLM_MAC) and another targeting tuna with live bait (HLM_TUN).

\section{Spatial distribution of fisheries by gear}

Bottom otter trawling was carried out on sedimentary bottoms outside the 100-m isobath, the legal limit (Fig. 3a). In the western part of the study area, the fishing effort was located close, but below, $200 \mathrm{~m}$ depth, although fishing activity between 100 and $200 \mathrm{~m}$ and deeper than $500 \mathrm{~m}$ was observed. In the eastern part, the effort distribution was similar, but higher activity could be observed near $100 \mathrm{~m}$. Bottom pair trawling was carried out in 3 areas: on the flanks of the Avilés Canyon and in the southern part of the rocky outcrop called El Agudo between depths of 200 and $500 \mathrm{~m}$ (Fig. 3b).

The set gillnet fishery (Fig. 3c) was conducted throughout the study area except in the eastern part above $200 \mathrm{~m}$. Two areas concentrate most of the effort: the eastern rocky area between 500 and $1,000 \mathrm{~m}$ and the region from west to southeast, around $100 \mathrm{~m}$. It is necessary to take into account that we do not have environmental information for the latter zone (Fig. 1) and thus do not know if rocky areas are present there.

In the case of set longline fishing, the 3 main areas subjected to fishing efforts were located over rocky bottoms: the headwater region of the Avilés Canyon, El Agudo rocky outcrop, and the area in front of Cape Peñas (Fig. 3d). Additionally, fishing activity was carried out along the flanks of the 3 canyons, between 500 and 1,000 m.

Most of the purse seine fishing activity was located in the western area of Cape Peñas below 100 m depth (Fig. 3e). Regarding handlines, the main activity was located at the head of the canyon, although the fishing effort was scattered over the entire area (Fig. 3f).

\section{Overlapping of demersal fishing activity}

Overlapping between the 2 types of trawls occurred in the northwestern zone and slightly in the northeastern part of Avilés Canyon (Fig. 4a). The overlap between gillnets and longlines was limited to the head of the canyon and the El Agudo outcrop (Fig. 4b). When comparing the spatial distribution between the mobile and set types of gears, the overlap was very low and only occurred in the northeastern part of Avilés Canyon (Fig. 5).

\section{Spatial distribution of fisheries by fishing tactic}

The spatial distribution of each fishing tactic can be seen in Figures S2-S5. Regarding otter trawling, the main difference was that the tactic targeting horse mackerel (OTB_HOM) was used mostly in the western area and along $100 \mathrm{~m}$ in the eastern zone. This fishing tactic and the tactic
Tres tácticas pesqueras emplearon redes de enmalle de fondo. Una fue dirigida a la merluza (GNS_HKE) y otra a Lophius spp. (rapes) (GNS_MNZ), sin que hubiera una especie accesoria característica. La tercer táctica fue dirigida a especies del grupo “otros” (GNS_MIX) con la merluza y los rapes como principales especies accesorias.

En el área de influencia del Sistema de Cañones de Avilés, el cerco y la línea de mano fueron utilizados en la captura de especies pelágicas. En el caso de la red de cerco, se identificaron 3 tácticas pesqueras: una dirigida al jurel (PS_HOM) con Boops boops (FO = 17) y Sardina pilchardus $(\mathrm{FO}=29)$ como principales especies accesorias, otra dirigida a la caballa (PS_MAC) y la tercera dirigida a la Sardina pilchardus (sardina) (PS_PIL) con el jurel $(\mathrm{FO}=19)$ y la caballa $(\mathrm{FO}=18)$ como especies accesorias. Por último, se identificaron 2 tácticas pesqueras con línea de mano: una dirigida a la caballa (HLM_MAC) y la otra dirigida a los túnidos con cebo vivo (HLM_TUN).

\section{Distribución espacial de las pesquerías por tipo de arte de pesca}

El arrastre de fondo con puertas se realizó en fondos sedimentarios por fuera de la isóbata de los $100 \mathrm{~m}$, que es el límite legal (Fig. 3a). En la zona occidental del área de estudio, el esfuerzo estuvó distribuido cerca, pero por debajo, de los $200 \mathrm{~m}$ de profundidad, aunque se detectó actividad pesquera entre 100 y $200 \mathrm{~m}$ y a más de $500 \mathrm{~m}$. En la zona oriental, la estructura fue similar, aunque la actividad fue más alta cerca de la isóbata de los $100 \mathrm{~m}$. El arrastre a la pareja se llevó a cabo en 3 zonas, en los flancos del cañón de Avilés $\mathrm{y}$ en el afloramiento rocoso al sur de El Agudo entre las isóbatas de 200 y 500 m (Fig. 3b).

En cuanto a los aparejos fijos, el enmalle (Fig. 3c) estuvo presente por casi toda la zona de estudio salvo en el extremo oriental cerca de los $200 \mathrm{~m}$. Dos zonas concentraron la mayor parte del esfuerzo: la zona rocosa del este entre las isóbatas de 500 y 1,000 m, y la zona que va del oeste al sudeste cerca de los $100 \mathrm{~m}$. Es necesario tener en cuenta que no tenemos información ambiental sobre esta última zona (Fig. 1), por lo que desconocemos si existen zonas rocosas.

En el caso de la pesquería con palangre de fondo, las 3 principales áreas de esfuerzo se localizaron sobre fondos rocosos: la cabecera del cañón de Avilés, el afloramiento rocoso de El Agudo y el área frente a cabo Peñas (Fig. 3d). Además, encontramos actividad pesquera en los flancos de los 3 cañones entre las isóbatas de 500 y 1,000 m de profundidad.

La mayor parte de la actividad pesquera con cerco se localizó en la zona occidental frente a cabo Peña por debajo de $100 \mathrm{~m}$ de profundidad (Fig. 3e). En cuanto a las líneas de mano, la actividad principal se localizó en la cabecera del cañón, aunque el esfuerzo pesquero se esparció por toda el área de studio (Fig. 3f). 

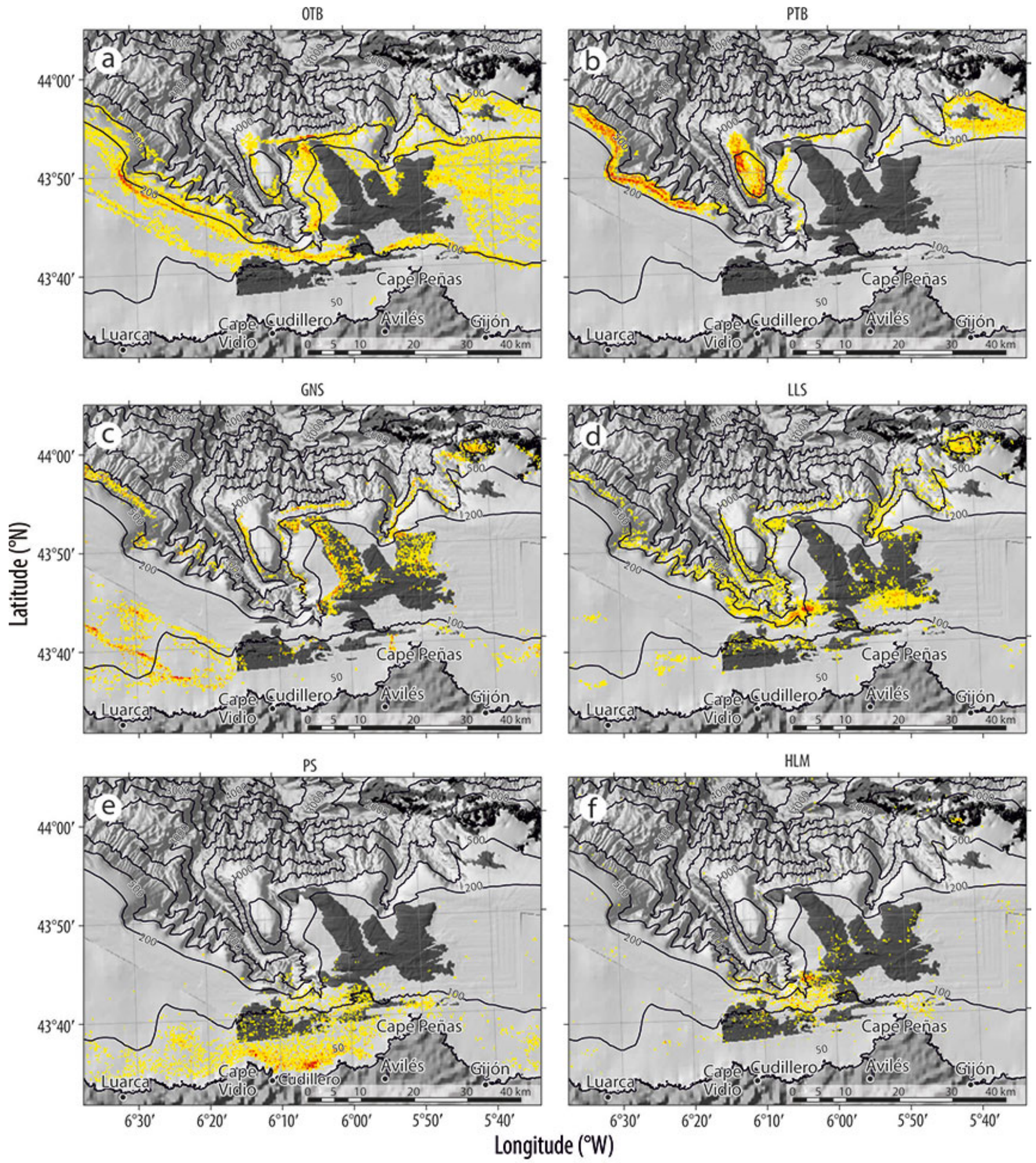

Longitude ( ${ }^{\circ} \mathrm{W}$ )

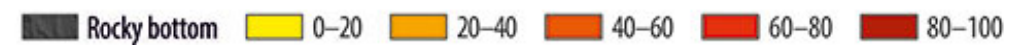

Figure 3. Spatial distribution by gear: (a) bottom otter trawl (OTB), (b) bottom pair trawl (PTB), (c) set gillnet (GNS), (d) set longline (LLS), (e) purse seine (PS), and (f) handline (HLM). Color scale indicates relative effort.

Figura 3. Distribución espacial por arte de pesca: (a) arrastre de fondo con puertas (OTB), (b) arrastre de fondo a la pareja (PTB), (c) enmalle de fondo fijo (GNS), (d) palangre de fondo fijo (LLS), (e) cerco (PS) y (f) línea de mano estática (HLM). La escala muestra el esfuerzo relativo. 
targeting mackerel (OTB_MAC) were carried out below $200 \mathrm{~m}$ depth (Fig. S2a-b). The mixed fishing tactic (OTB_MIX) was observed in the whole area where this fishing gear was used (Fig. S2c). The OTB_MAC tactic was carried out during the first 5 months of the year.

In the case of bottom pair trawling, we found 2 very different distribution patterns of effort for each fishing tactic. Thus, whereas the tactic targeting blue whiting (PTB_WHB) was spread across the entire area where pair trawling was carried out (Fig. S2d), the tactic targeting mackerel was centered on the western part of the continental margin of Avilés Canyon from 200 to $500 \mathrm{~m}$ depth (Fig. S2e). As observed for OTB_MAC, PTB_MAC was carried out during the first 5 months of the year.

Each of the 3 gillnet fishing tactics presented a different spatial distribution (Fig. S3). In the case of the mixed fishery (GNS_MIX), there did not appear to be any defined pattern, and this fishery operated throughout the entire area where gillnets were used. Gillnetting for hake (GNS_HKE) was carried out in the western area of the continental shelf, between 100 and $200 \mathrm{~m}$ depth, and in the rocky area located in front of Cape Peñas. We did not have any information on the type of bottom in the western part of the platform and the eastern end at $100 \mathrm{~m}$ depth. In the case of the tactic targeting monkfish (GNS_MNZ), this activity was carried out at depths between 500 and 1,000 $\mathrm{m}$ and within the limits between the soft and rocky substrata surrounding the rocky area located in front of Cape Peñas.

The longline fishing tactic targeting forkbeard (LLS_GFB) was carried out primarily in the deep-sea areas located on the flanks of the three canyons, between 500 and 1,000 m depth (Fig. S4a). The tactic targeting conger (LLS_COE) was used at a shallower depth along the rocky area in front of Cape Peñas and at the $100 \mathrm{~m}$ depth contour line (Fig. S4b). The fishing effort of the tactic targeting hake (LLS_HKE) was concentrated in the headwaters of Avilés Canyon, in El Agudo, and in the outcrops located in front of Cape Peñas (Fig. S4c). The LLS_POL tactic was mainly used along the $100-\mathrm{m}$ isobath (Fig. S4d).

The spatial distributions of the purse seine fishing techniques targeting horse mackerel and sardine were very similar because the fishing activity was carried out close to the shore and to the west of Cape Peñas (Fig. S5a-b). In the case of the fishery targeting mackerel, the fishing effort was concentrated in the middle of the continental shelf and close to the headwaters of the canyon (Fig. S5c). As for seasonality, all of the fishing tactics targeting mackerel were carried out during the first 4 months of the year.

In the case of handline fishing for mackerel, the effort distribution was very similar to purse seine targeting the same species (Fig. S5d). The tactic targeting tuna was carried out in the rocky area located in the waters of Avilés Canyon and in El Agudo (Fig. S5e).

\section{Solapamiento de la actividad pesquera demersal}

El solapamiento de los 2 tipos de arrastre ocurrió en la zona noroccidental, y fue escaso en la parte nororiental del cañón de Avilés (Fig. 4a). El solapamiento entre enmalle y palangre estuvo limitado a la cabecera del cañón y en El Agudo (Fig. 4b). Cuando se comparó la distribución espacial entre los tipos de artes de pesca, móviles y fijos, el solapamiento fue muy bajo, y sólo ocurrió en la parte nororiental del cañón de Avilés (Fig. 5).

\section{Distribución espacial de las pesquerías por táctica pesquera}

La distribución espacial de cada una de las tácticas pesqueras puede verse en las Figuras S2-S5. En el caso de las tácticas con arrastre de fondo con puertas, la diferencia más importante fue que la táctica dirigida al jurel (Trachurus spp.) (OTB_HOM) se llevó a cabo principalmente en la zona occidental y a lo largo de la isóbata de los $100 \mathrm{~m}$ en la zona oriental. Esta táctica pesquera y la táctica dirigida a la caballa (OTB_MAC) se desarrollaron principalmente a profundidades menores que $200 \mathrm{~m}$ (Fig. S2a-b). La táctica pesquera mixta (OTB_MIX) se aplicó en toda el área ocupada por este arte de pesca (Fig. S2c). La táctica OTB_MAC se llevó a cabo durante los primeros 5 meses del año.

En el caso del arrastre de fondo a la pareja, el patrón de la distribución del esfuerzo con las 2 tácticas pesqueras es muy distinto. Mientras que la táctica dirigida al lirio (PTB_WHB) ocupó toda el área de distribución del arrastre a la pareja (Fig. S2d), la táctica pesquera dirigida a la caballa se concentró en el borde continental del oeste del cañón de Avilés, entre las isóbatas de 200 y $500 \mathrm{~m}$ (Fig. S2e). Al igual que en el caso del OTB_MAC, la táctica PTB_MAC se llevó a cabo en los primeros 5 meses del año.

Las 3 tácticas pesqueras con el enmalle tuvieron una distribución espacial diferente (Fig. S3). La táctica pesquera mixta (GNS_MIX) pareció no tener un patrón claro, y se distribuyó en toda la zona donde estuvo presente el enmalle. La táctica pesquera de enmalle dirigida a la merluza (GNS_HKE) se desarrolló en la zona occidental de la plataforma continental entre 100 y $200 \mathrm{~m}$ de profundidad y en la zona rocosa frente a cabo Peñas. Carecemos de información sobre el tipo de fondo en la zona occidental de la plataforma y en el extremo oriental a $100 \mathrm{~m}$ de profundidad. La táctica pesquera dirigida al rape (GNS_MNZ) se desarrolló a mayor profundidad, entre 500 y 1,000 m, y en los límites entre el sustrato blando y rocoso, alrededor de la zona rocosa frente a cabo Peñas.

La táctica pesquera con palangre de fondo dirigida a la locha (LLS_GFB) se desarrolló principalmente en zonas profundas de los flancos de los 3 cañones, entre 500 y 1,000 m (Fig. S4a). La táctica pesquera dirigida al congrio (LLS_COE), se llevó a cabo a menor profundidad, en la zona 

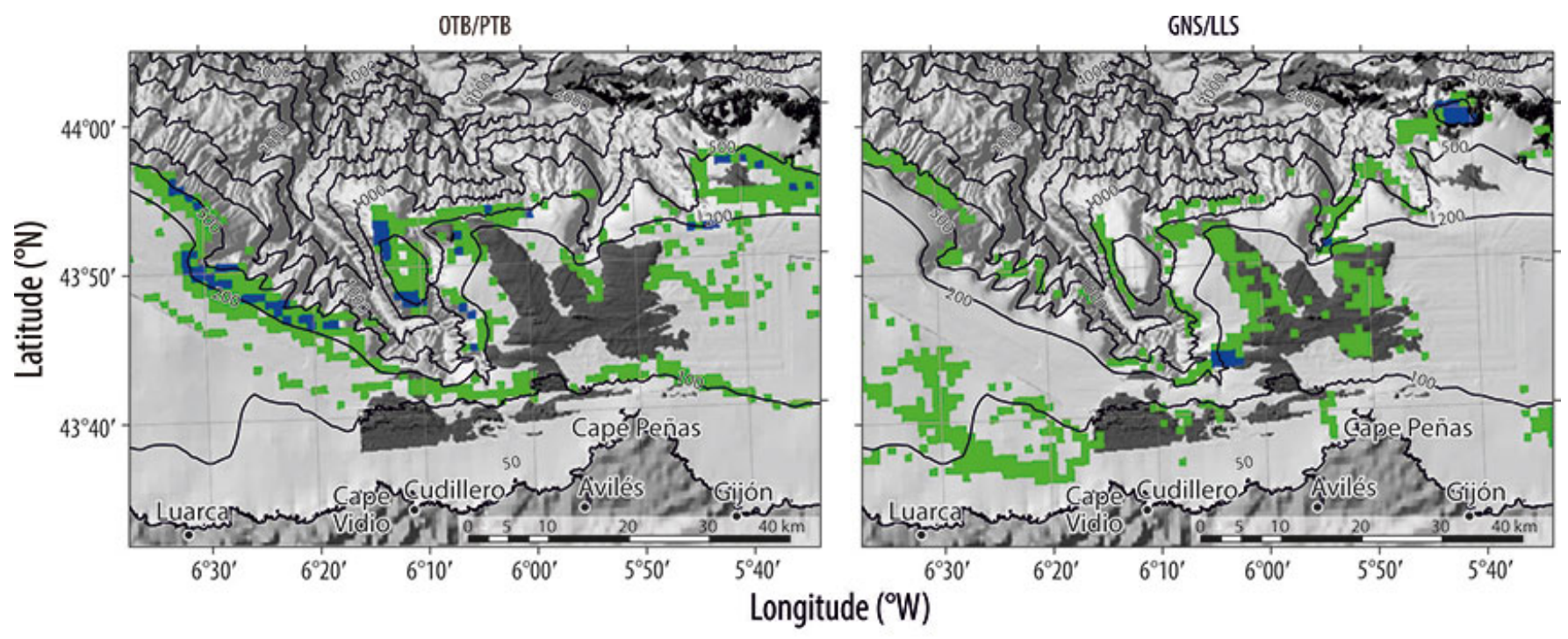

Rocky bottom

Activity

Overlap

Figure 4. Spatial distribution of the overlapping between demersal fisheries: (a) bottom otter trawl (OTB) and bottom pair trawl (PTB), and (b) set gillnet (GNS) and set longline (LLS).

Figura 4. Distribución espacial del solapamiento entre pesquerías demersales: (a) arrastre de fondo con puertas (OTB) y arrastre de fondo a la pareja (PTB) y (b) enmalle de fondo fijo (GNS) y palangre de fondo fijo (LLS).

\section{Discussion}

On narrow continental shelves subjected to strong fishing pressure, as in the case of the study area, fishing tactics are used in different areas to share the space available and avoid friction caused by the spatial overlapping of fishing activities. In this context, and considering the strong spatial segregations observed in this study, the filters used to eliminate signals not corresponding to fishing activity were effective. The validity of these filters was checked by analyzing the spatial distribution of bottom trawling because this fishing gear can be used only on sedimentary bottoms and is subject to specific legal regulations. Once filtering techniques were applied, trawling was not observed at depths above $100 \mathrm{~m}$ (closed zone to bottom trawling in Spanish territorial waters in the North Atlantic) or in harbor entrances. The fleet using bottom trawling cannot operate in rocky areas and, as we observed, bottom trawling fishing tactics were not used on rocky bottoms.

In the case of fishing gears already described in previous studies, the same structure was obtained for the fishing tactics (Castro et al. 2010, Punzón et al. 2011). Among those identified, mixed gillnet (GNS_MIX) should not be considered a fishing tactic even though it presents a high partial silhouette coefficient value (Table 2). This high value can be attributed to the inclusion of a large number of underrepresented species in the "other" group. In addition, it was necessary to take into account that the main bycatches were hake and monkfish and that the spatial distribution of GNS_MIX appeared to be the result of the GNS_HKE and rocosa frente a cabo Peñas y a lo largo de la isóbata de $100 \mathrm{~m}$ (Fig. S4b). El esfuerzo con la táctica dirigida a la merluza (LLS_HKE) se concentró en la cabecera del cañón de Avilés, en El Agudo y en los afloramientos rocosos situados frente a cabo Peñas (Fig. S4c). La táctica LLS_POL se aplicó principalmente a lo largo de la isóbata de $100 \mathrm{~m}$ (Fig. S4d).

La tácticas pesqueras con cerco dirigidas al jurel y a la sardina tuvieron una distribución espacial muy similar, y se realizaron muy cerca de la costa y al oeste de cabo Peñas (Fig. S5a, b). En el caso de la táctica dirigida a la caballa, el esfuerzo se concentró en la mitad de la plataforma continental, cerca de la cabecera del cañón (Fig. S5c). En lo que respecta a la estacionalidad, la táctica pesquera dirigida a la caballa, al igual que el resto de las tácticas que tuvieron a esta especie como objetivo, se llevó a cabo en los 4 primeros meses del año.

En el caso de la táctica pesquera con línea de mano dirigida a la caballa, el esfuerzo presentó una distribución muy similar a la de la táctica con cerco dirigida a esta misma especie (Fig. S5d). La táctica pesquera dirigida a túnidos se llevó a cabo en la zona rocosa de la cabecera del cañón de Avilés y en El Agudo (Fig. S5e).

\section{DISCUSIÓN}

En las plataformas continentales estrechas donde existe una fuerte presión pesquera, como es el caso de la zona de estudio, las diferentes tácticas pesqueras suelen llevarse a cabo estratégicamente en zonas repartidas del espacio disponible para evitar, en lo posible, fricciones relativas al 


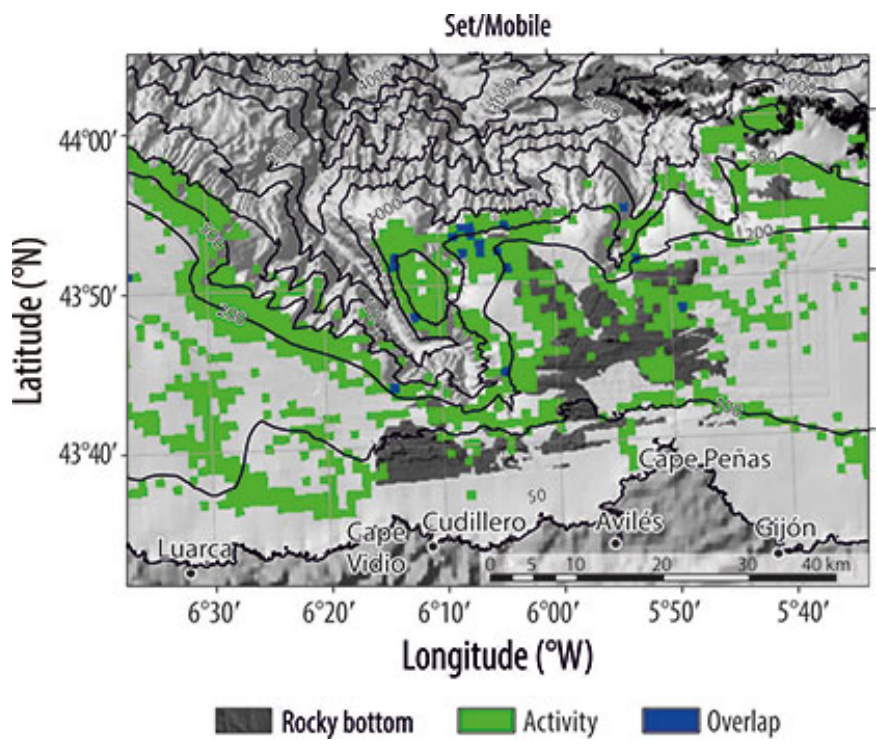

Figure 5. Spatial distribution of the overlapping between mobile gear (otter trawl and pair trawl) and set gear (gillnet and longline).

Figura 5. Distribución espacial del solapamiento entre artes de pesca móviles (arrastre de fondo con puertas y arrastre de fondo a la pareja) y fijas (enmalle de fondo y palangre de fondo).

GNS_MNZ distributions, so it was probable that catches from the latter tactics were being included in the first.

Using statistical rectangles to define if a fishery should be considered a deep-water fishery, like LLS_COE, may be problematic in narrow continental shelves (Punzón et al. 2011). As we have observed, the activity of this fishery takes place along the entire continental shelf, including the area close to the 500-m contour line, and for that reason it should be considered a deep-sea fishery. Therefore, the VMS is a powerful tool to characterize the fisheries in narrow continental shelves, especially for fisheries operating in areas of special interest where spatial management measures are to be implemented.

In the reviews conducted by Piñeiro et al. (2001) and Punzón et al. (2011), the authors identified 2 deep-water fisheries in the Northeast Atlantic region: GNS_MNZ and OTB_MIX. In the case of GNS_MNZ, the fishing effort was located below $500 \mathrm{~m}$ depth, while in the case of OTB_MIX, the fishing effort deeper than $500 \mathrm{~m}$ was carried out only in the western region and was not very intense. Although some fishing activity of PTB_WHB and LLS_HKE was observed close to the 500-m contour line, we could not determine whether these activities should be considered deep-water fisheries or not because it was not clear whether they were carried out below $500 \mathrm{~m}$ depth.

The spatial distribution of fisheries by type of fishing gear showed that they barely interacted in the study area, at least not in zones with the highest fishing effort. This small overlap implies that almost all the study area is subject to solapamiento de actividades pesqueras. En este sentido, y teniendo en cuenta la fuerte segregación espacial observada, los filtros empleados para eliminar todas aquellas señales que eran ajenas a la actividad pesquera fueron efectivos. La validez de estos filtros la podemos comprobar al analizar la distribución espacial del arrastre de fondo, ya que este aparejo puede arrastrar sólo en fondos sedimentarios y tiene restricciones legales muy precisas. Una vez aplicado el umbral, no hubo presencia de arrastre a menos de $100 \mathrm{~m}$ (veda espacial de pesca para el arrastre en la zona de estudio) ni en las entradas a los puertos de pesca. La flota que utiliza arrastre de fondo no puede trabajar en zonas rocosas y, como podemos comprobar, ningúna táctica pesquera con arrastre fue operada en la zona rocosa.

Para las artes de pesca ya descritas en estudios previos, la estructura de las tácticas pesqueras fue igual a la obtenida en este trabajo (Castro et al. 2010, Punzón et al. 2011). Entre las tácticas pesqueras identificadas, el enmalle mixto (GNS_MIX) no debería ser considerado una táctica pesquera, a pesar de haber presentado un alto coeficiente parcial de silueta (Tabla 2). Este alto coeficiente puede deberse a la inclusión de un gran número de especies pobremente representadas dentro del grupo de “otros”. Además, hay que tener en cuenta que las principales especies accesorias fueron la merluza y el rape, y que la distribución espacial de GNS_MIX parece ser el resultado de las distribuciones de GNS_HKE y GNS_MNZ; por lo tanto, es probable que las mareas de estas últimas tácticas pesqueras estén incluidas en la primera.

Para las plataformas continentales estrechas, el uso de los rectángulos estadísticos para definir si una pesquería debe ser considerada pesquería de profundidad, como LLS_COE, puede ser difícil (Punzón et al. 2011). Como hemos visto, esta táctica pesquera se practica a lo largo de toda la plataforma continental, incluso en la zona próxima a la isóbata de $500 \mathrm{~m}$, por lo que debería ser considerada una pesquería de profundidad. Por lo tanto, el SSB es una herramienta importante para caracterizar las pesquerías en plataformas continentales estrechas, especialmente las pesquerías que operan en áreas de especial interés donde se van a implementar medidas de gestión espacial.

En las revisiones realizadas por Piñeiro et al. (2001) y Punzón et al. (2011), los autores identificaron 2 pesquerías de profundidad en la región del Atlántico nororiental: GNS_MNZ y OTB_MIX. En el caso de GNS_MNZ, el esfuerzo pesquero se localizó por debajo de $500 \mathrm{~m}$ de profundidad, mientras que en el caso de OTB_MIX, el esfuerzo a más de $500 \mathrm{~m}$ de profundidad se llevó a cabo en la región occidental y no fue muy intenso. Aunque se indentificó actividad pesquera de PTB_WHB y LLS_HKE cerca de la isóbata de $500 \mathrm{~m}$, ésta tampoco fue muy importante, y no fue posible determinar si estas actividades pueden ser consideradas pesquerías de profundidad o no porque no fue muy claro si se llevaron a cabo por debajo de los $500 \mathrm{~m}$. 
fishing effort; however, there is little competition between the fishing techniques for common resources. The almost non-existent overlap among the various types of activity will further serve to allocate fishing techniques with pings that were not used in the past due to the lack of logbook information (Russo et al. 2011).

Of the 2 trawling techniques used in the area, otter trawling was carried out in larger areas. This distinction was due to the fact that bottom otter trawls are smaller longitudinally and narrower at the mouth, so this fishing gear can be handled more easily. In other words, because of its better handling qualities and minor surface contact, this fishing gear can be used in narrower and rougher fishing grounds. Bottom otter trawls can also be used in the same fishing grounds where pair trawling is being carried out. However, in these areas, otter trawling activity was low. The main reason was that pair trawling targeted blue whiting, a species inhabiting the break shelf (Castro et al. 2010), but it ceased to be the target species at the beginning of the 21st century (Punzón et al. 2010). Since these fisheries did not compete for the same resource, they operated in different locations. Both trawling techniques were limited to specific areas, and they were carried out at a constant depth following the bathymetry to avoid affecting artisanal fisheries. The region located on the east side of the study area had a wider continental shelf and a smoother sea bottom. In this area, trawling patterns were changeable compared with the shelf break and rocky zones. This was possible because of the small number of artisanal fisheries operating in the western region of the continental platform, leaving this area to be used exclusively for trawling. However, the number of fisheries increased considerably in the shelf breaks, so the trawling patterns became more regular.

The main spatial overlap between fishing tactics was observed between gillnets targeting monkfish and longlines targeting hake in the rocky outcrop called El Agudo. The bulk of the fishing effort exerted in this area was related to gillnet fishing, whereas the activity related to longline fishing was of less importance. To determine the extent of the interaction between the different fishing gears in the area, we need further information about the characteristics of the local fishing fleet.

It is worth mentioning that the different fishing tactics were located in distinct areas depending on the sea bottom characteristics and, in the particular case of sandy bottoms, on the substrate type. Thus, the spatial distribution of the different tactics and fishing gears used was strongly influenced by this variable in the study area, affecting the way the fishing activity was interpreted. For instance, GNS_HKE was present in the rocky area where information about the sea bottom was available, whereas in the western part of the continental shelf, where we did not have information about the bottom type, its spatial distribution appeared to be related to a specific type of sea bottom. Thus, it was difficult to define the spatial interactions between fishing gears when this information was not available.
La distribución espacial de las pesquerías por tipo de arte de pesca muestra que existe un escaso solapamiento en la zona de estudio, al menos en las zonas con altos niveles de esfuerzo. El escaso solapamiento implica que casi toda la zona de estudio está sometida a esfuerzo pesquero; sin embargo, hay poca competencia entre las técnicas pesqueras para recursos comunes. La casi inexistencia de solapamiento entre varios tipos de actividad debería permitirnos asignar técnicas pesqueras a aquellos pings a los que no se les pudo asignar la información de los cuadernos de pesca (Russo et al. 2011).

En el caso de los 2 tipos de arrastre con los que se trabaja en la zona, el arrastre con puertas ocupó una mayor área. Esto es debido a que la red de arrastre de fondo con puertas es más pequeña longitudinalmente y tiene menos abertura horizontal y, por lo tanto, las necesidades para trabajar son menos exigentes. Es decir, debido a su mayor maniobrabilidad, puede trabajar en caladeros de pesca más estrechos y angostos, y al tener menos superficie de contacto con el fondo, el terreno no necesita ser tan uniforme. El arrastre de fondo con puertas puede ser usado en los mismos caladeros de pesca donde se usa el arrastre a la pareja. Sin embargo, en estas áreas, la actividad del arrastre con puertas fue bajo. Esto es debido principalmente a que la especie principal objetivo del arrastre a la pareja es el lirio (Castro et al. 2010), y esta especie, que habita principalmente en el talud continental, dejo de ser objetivo para el arrastre a principios del siglo XXI (Punzón et al. 2010). Por lo tanto, al no competir por los mismos recursos, las pesquerías podrían ocupar espacios distintos. Para ambas artes de pesca, las zonas de arrastre, además de quedar restringidas por el tipo de fondo, siguen la batimetría intentando mantener la profundidad durante el arrastre e interferir lo menos posible con las pesquerías artesanales. En la región situada al este de la zona de estudio, la plataforma es más ancha y aplacerada. En esta área, las orientaciones del arrastre pueden cambiar y no seguir un patrón único como en las zonas de talud o en zonas de fondo rocoso. Esto es posible debido a la poca ocupación que hacen las pesquerías fijas artesanales de esta región oriental de la plataforma continental, que queda de uso exclusivo del arrastre. Sin embargo, en el talud se incrementa considerablemente la competencia por el espacio de las diferentes pesquerías, lo que las obliga a mantener rumbos fijos.

Los solapamientos más importantes entre las tácticas pesqueras se dan entre el enmalle dirigido al rape y el palangre dirigido a la merluza en la zona del afloramiento rocoso de El Agudo. Esta es una zona muy importante para la pesca con enmalle dirigida al rape, mientras que para la pesca con palangre dirigida a la merluza, en cuanto a esfuerzo, se trata de una zona secundaria. Para determinar el grado de conflicto de uso entre aparejos, sería necesario determinar si esta zona es explotada por flotas con alguna singularidad local.

Es importante destacar que la distribución de las distintas tácticas pesqueras depende de las características del fondo y, en el caso de los sustratos blandos, del tipo de sustrato. Esta 
Hake, mackerel, and horse mackerel were targeted by more than one fishing tactic in the study area. In the case of hake, the spatial overlap between the two tactics (LLS_HKE and GNS_HKE) was not important. Therefore, hake was caught by longline gear in the head of Avilés Canyon, whereas gillnetting was used in the rocky area in front of Cape Peñas and in the western area between 100 and $200 \mathrm{~m}$ depth. Spatial overlap was only found at El Agudo, although the longline efforts were very low in this zone.

From the end of winter to early spring, the main fishing effort in the southern part of the Bay of Biscay is directed at mackerel during its reproductive migration (Uriarte and Lucio 2001, Villamor et al. 2011). Most of the fishing gears employed in the area are used to catch mackerel (Punzón et al. 2004). This pattern could have led to a decrease in the fishing efforts of other fishing tactics, but it was only observed for bottom trawling targeting mackerel from February to March. The fishing activity of all the tactics directed at mackerel was located on the continental shelf surrounding Cape Peñas. Fisheries targeting small and medium pelagic fish generally operated in offshore waters. Only purse seine fishing was carried out close to the coast, but the bulk of the fishing effort was located beyond $100 \mathrm{~m}$. This pattern might be explained by the fact that the targeted species has to round Cape Peñas during its migration from east to west, resulting in higher abundances of this species on the mid and outer continental shelf.

The use of VMS information together with information from logbooks allowed us to study not only the spatiotemporal pattern of fishing activity but also fundamental aspects of fisheries management and the ecosystems affected by this activity. In this context, we can gain knowledge of the ecosystem structures with respect to commercial species, including information about non-accessible areas for research surveys carried out in the study area based on trawling hotspots (Sánchez and Serrano 2003), which were spatially limited to sedimentary bottoms and temporarily limited during autumn. Moreover, this research allowed us to study the behavior of commercial species because the VMS signals associated with a specific catch can be interpreted as the presence of the species. The use of this information in combination with environmental data obtained from other sources could lead to a better understanding of the environmental conditions in which these catches are carried out.

Finally, by knowing the distribution patterns of fishing activity and the biological and environmental variables determining these distributions, we could predict their responses to different management measures. Thus, we could simulate the effect of different fishing effort distributions in the area before establishing MPAs if fishing activity were modified or if mutually exclusive activities were carried out. This knowledge will allow us to estimate the social and economic impacts on fishing activity as well as on the mortality of the targeted species. variable condiciona, en gran medida, la distribución espacial de cada una de las tácticas pesqueras en la zona de estudio y, sobre todo, el tipo de aparejo a utilizar. Esto afecta a la interpretación de la actividad pesquera. Así, por ejemplo, el GNS_HKE, en la zona donde disponemos de información del tipo de fondo, está distribuido en la zona rocosa, mientras que en la zona occidental de la plataforma, en donde carecemos de la información del tipo de fondo, parece tener una distribución espacial que invita a pensar que sigue un patrón asociado a algún tipo de fondo específico. Por lo tanto, es difícil en muchas ocasiones definir la competencia espacial entre aparejos sin esta información.

La merluza, la caballa y el jurel fueron especies objetivo para más de una táctica pesquera en la zona de estudio. En el caso de la merluza, el solapamiento espacial entre las 2 tácticas pesqueras (LLS_HKE y GNS_HKE) no fue importante. Mientras que con el palangre se explota principalmente la zona de la cabecera del cañón de Avilés, con el enmalle se explota la zona rocosa frente al cabo Peñas y la zona occidental entre 100 y $200 \mathrm{~m}$. Se apreció algo de solapamiento solamente en El Agudo, aunque el esfuerzo de palangre en esa zona fue muy bajo.

Entre el final del invierno y el comienzo de la primavera una parte importante del esfuerzo se dirigió a la caballa durante la migración reproductora de esta especie (Uriarte y Lucio 2001, Villamor et al. 2011). La mayoría de los aparejos utilizados en la zona de estudio son utilizados para la captura de la caballa (Punzón et al. 2004). Este efecto debería provocar un descenso en el esfuerzo de otras tácticas pesqueras, pero sólo se detectó en febrero y marzo para la táctica con arrastre de fondo con puertas dirigida al jurel. Todas las tácticas pesqueras dirigidas a la caballa ocupan toda la plataforma continental por fuera de cabo Peñas. De todas las pesquerías dirigidas a pequeños y medianos pelágicos, la pesquería de la caballa es la que se desarrolla más alejada de la costa de forma general. Solamente el esfuerzo con cerco mantuvo cierta actividad cerca de la costa, aunque la mayor parte del esfuerzo es por fuera de la isóbata de los $100 \mathrm{~m}$. Esto puede deberse a que durante su migración desde el este hacia el oeste, $y$ al verse obligada a evitar el cabo Peñas, la caballa presenta las mayores abundancias en la plataforma media y externa.

La información de los SSB combinada con la de los cuadernos de pesca nos ha permitido estudiar no sólo la distribución espaciotemporal de la actividad pesquera, sino otros aspectos que son fundamentales en la gestión de los recursos y los ecosistemas que los soportan. Nos permite completar conocimientos acerca de la estructura de los ecosistemas, a nivel de especies comerciales, además de información de áreas no accesibles para las campañas de investigación basadas en lances de arrastre que se desarrollan en la zona (Sánchez y Serrano 2003), generalmente limitadas tanto espacial (sólo en fondos sedimentarios) como temporalmente (sólo en otoño). Además nos permite realizar estudios sobre el comportamiento de las especies de interés comercial, ya 


\section{ACKNOWLEDGMENTS}

This study was partially funded by the TEPESCO project (2016, Instituto Español de Oceanografía) and by the European Commission LIFE+ "Nature and Biodiversity" program (INDEMARES project 07/NAT/E/000732); the Biodiversity Foundation of the Ministry of Environment was the institution responsible for coordinating the latter. The bathymetric information and ground characteristics were made available thanks to the invaluable work of María Druet, María Gómez-Ballesteros, and Araceli MuñozRecio.

\section{REFERENCES}

Baelde P. 2005. Interactions between the implementation of marine protected areas and right-based fisheries management in Australia. Fish. Manage. Ecol. 12: 9-18.

Campos A, Fonseca P, Fonseca TJ, Parente J. 2007. Definition of fleet components in the Portuguese bottom trawl fishery. Fish. Res. 83: 185-191

Castro J, Punzón A, Pierce GJ, Marín M, Abad E. 2010. Identification of métiers of the northern Spanish coastal bottom pair trawl fleet by using the partitioning method CLARA. Fish. Res. 102: 184-190.

Claudet J, Pelletier D. 2004. Marine protected areas and artificial reefs: A review of the interactions between management and scientific studies. Aquat. Living Resour. 17: 129-138.

Cury PM, Mullon C, García SM, Shannon LJ. 2005. Viability theory for an ecosystem approach to fisheries. ICES J. Mar. Sci. 62: 577-584.

Dray S, Dufour AB. 2007. The ade4 package: Implementing the duality diagram for ecologists. J. Stat. Softw. 22: 1-20.

Fréon P, Drapeau L, David JH, Fernandez Moreno A, Leslie RW, Oosthuizen WH, Shannon LJ, van der Lingen CD. 2005. Spatialized ecosystem indicators in the southern Benguela. ICES J. Mar. Sci. 62: 459-468.

García SM, Cochrane KL. 2005. Ecosystem approach to fisheries: A review of implementation guidelines. ICES J. Mar. Sci. 62: 311-318.

Gislason H, Sinclair M, Sainsbury K, Boyle R. 2000. Symposium overview: Incorporating ecosystem objectives in fisheries management. ICES J. Mar. Sci. 57: 468-475.

Gómez-Ballesteros M, Druet M, Muñoz A, Arrese B, Rivera J, Sánchez F, Cristobo J, Parra S, García-Alegre A, González-Pola C, Gallastegui J, Acosta J. 2014. Geomorphology of the Avilés Canyon System, Cantabrian Sea (Bay of Biscay). Deep-Sea Res. (II): 106: 99-117.

Hintzen N, Bastardie F, Beare D, Piet G, Ulrich C, Deporte N, Egekvist J, Degel H. 2011. VMStools: Open-source software for the processing, analysis and visualization of fisheries logbook and VMS data. Fish. Res. 115: 31-43.

Hollingworth CE (ed.). 2000. Ecosystem Effects of Fishing. Proceedings of an ICES/SCOR Symposium held in Montpellier, France, March 1999. ICES J. Mar. Sci. 57: 465-791.

[ICES] International Council for the Exploration of the Sea. 2003. Study Group on the Development of Fishery-based Forecasts. ICES CM 2003/ACFM:08, Boulogne, France.

Jennings S, Kaiser M. 1998. The effects of fishing on marine ecosystems. Adv. Mar. Biol. 34: 201-352.

Jiménez MP, Sobrino I, Ramos F. 2004. Objective methods for defining mixed-species trawl fisheries in Spanish waters of the Gulf of Cádiz. Fish. Res. 67: 195-206. que las señales del SSB asociadas a una especie capturada se pueden interpretar como presencia de esa especie. Estas características se pueden combinar con información ambiental procedente de otras fuentes y, por lo tanto, podrían permitirnos conocer mejor las condiciones ambientales en las que se realiza la captura y consecuentemente los hábitats de las especies.

Una vez obtenidos los patrones de distribución espacial de la actividad pesquera y las variables ambientales y biológicas que los condicionan, se puede modelar el comportamiento de la actividad pesquera como respuesta a determinadas medidas de gestión. Por lo tanto, antes del establecimiento de un área marina protegida, por ejemplo, se podrá simular la reubicación espacial del esfuerzo en caso de que se excluyan o modifiquen determinadas actividades. Esto nos permitirá, además, estimar las consecuencias sobre la actividad pesquera, los efectos sociales y económicos, y los cambios sobre la mortalidad de las especies objetivo.

\section{Agradecimientos}

Este estudio fue parcialmente financiado por el proyecto TEPESCO (2016, Instituto Español de Oceanografía) y el programa LIFE+ de la Comisión Europea (proyecto INDEMARES 07/NAT/E/000732), el cual fue coordinado por la Fundación Biodiversidad del Ministerio de Medio Ambiente de España. La información de la batimetría y las características del suelo fueron el producto del trabajo invaluable de María Druet, María Gomez-Ballesteros y Araceli MuñozRecio.

Jiménez-Valverde A, Lobo J. 2007. Threshold criteria for conversion of probability of species presence to either-or presence-absence. Acta Oecol. 31: 361-369.

Jones PJ. 2001. Marine protected area strategies: Issues, divergences and the search for middle ground. Rev. Fish Biol. Fish. 11: 197-216.

Kaufman L, Rousseeuw PJ. 1986. Clustering large sets (with discussion). In: Gelsema ES, Kanal LN (eds.), Pattern Recognition in Practice II. Elsevier/North Holland, Amsterdam, pp. 405-416.

Lee J, South AB, Jennings S. 2010. Developing reliable, repeatable, and accessible methods to provide high-resolution estimates of fishing-effort distributions from vessel monitoring system (VMS) data. ICES J. Mar. Sci. 67: 1260-1271.

Link JS. 2005. Translating ecosystem indicators into decision criteria. ICES J. Mar. Science. 62: 569-576.

Maechler M, Rousseeuw PJ, Struyf A, Hubert M. 2005. Cluster: Cluster Analysis Basics and Extensions. R package version 1.10.2, http://cran.r-project.org/web/packages/cluster/.

Marchal P, Andersen B, Bromley D, Iriondo A, Mahévas S, Quirijns F, Rackham B, Santurtún M, Tien N, Ulrich C. 2006. Improving the definition of fishing effort for important European fleets by accounting for the skipper effect. Can. J. Fish. Aquat. Sci. 63: 510-533. 
Pauly D, Christensen V, Guénette S, Pitcher TJ, Sumaila UR, Walters CJ, Watson R, Zeller D. 2002. Towards sustainability in world fisheries. Nature 418: 689-695.

Pikitch EK, Santora C, Babcock EA, Bakun A, Bonfil R, Conover DO, Dayton P, Doukakis P, Fluharty D, Heneman B, Houde ED, Link J, Livingston PA, Mangel M, McAllister MK, Pope J, Sainsbury KJ. 2004. Ecosystem-based fishery management. Science 305: 346-347.

Piñeiro C, Casas M, Bañón R. 2001. The deep-water fisheries exploited by Spanish fleets in the Northeast Atlantic: A review of the current status. Fish. Res. 51: 311-320.

Punzón A, Hernández C, Abad E, Castro J, Pérez N, Trujillo V. 2010. Spanish otter trawl fisheries in the Cantabrian Sea. ICES J. Mar. Sci. 67: 1-13.

Punzón A, Serrano A, Castro J, Abad E, Gil J, Pereda P. 2011. Deepwater fishing tactics of the Spanish fleet in the Northeast Atlantic. Seasonal and spatial distribution. Sci. Mar. 75: 465-476.

Punzón A, Villamor B, Preciado I. 2004. Analysis of the handline fishery targeting mackerel (Scomber scombrus, L.) in the north of Spain (ICES Division VIIIbc). Fish. Res. 69: 189-204.

R Development Core Team. 2005. R: A language and environment for statistical computing. $\mathrm{R}$ Foundation for Statistical Computing, Vienna, Austria. ISBN 3-900051-07-0, URL http:// www.R-project.org.
Rousseeuw PJ. 1987. Silhouettes: A graphical aid to the interpretation and validation of cluster analysis. J. Comput. Appl. Math. 20: 53-65.

Russo T, Parisi A, Cataudella S. 2011. New insights in interpolating fishing tracks from VMS data for different métiers. Fish. Res. 108: 184-194.

Sánchez F, Olaso I. 2004. Effects of fisheries on the Cantabrian Sea shelf ecosystem. Ecol. Model. 172: 151-174.

Sánchez F, Serrano A. 2003. Variability of groundfish communities of the Cantabrian Sea during the 1990s. ICES Mar. Sci. 219: 249-260.

Sinclair M, Arnason R, Csirke J, Karnicki Z, Sigurjonsson J, Rune Skjoldal H, Valdimarsson G. 2002. Responsible fisheries in the marine ecosystem. Fish. Res. 58: 255-265.

Struyf A, Mia H, Rousseeuw PJ. 1996. Clustering in an objectoriented environment. J. Stat. Softw. 1(4): 1-30.

Uriarte A, Lucio P. 2001. Migration of adult mackerel along the Atlantic European shelf edge from a tagging experiment in the south of the Bay of Biscay in 1994. Fish. Res. 50: 129-139.

Villamor B, González-Pola C, Lavín A, Valdés L, Lago de Lanzón A, Franco C, Cabanas JM, Bernal M, Hernández C, Iglesias M, Carrera P, Porteiro C. 2011. Environmental control of Northeast Atlantic mackerel (Scomber scombrus) recruitment in the southern Bay of Biscay: Case study of failure in the year 2000 . Fish. Oceanogr. 20: 397-414.

Received December 2015, accepted October 2016. 


\section{Supplementary material}
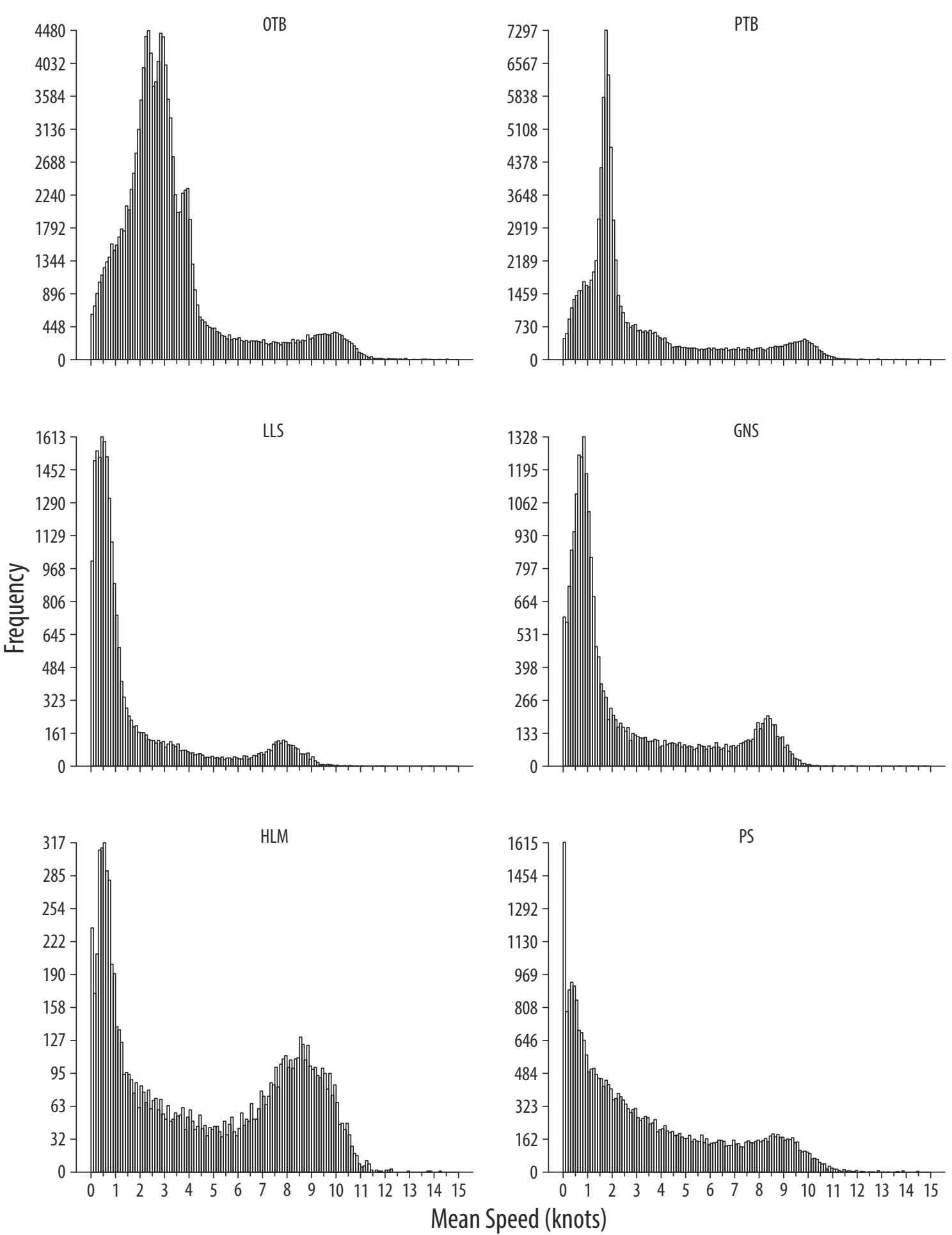

Figure S1. Distribution of the mean speed by gear: bottom otter trawl (OTB), bottom pair trawl (PTB), set gillnet (GNS), set longline (LLS), purse seine (PS), and handline (HLM).

Figura S1. Distribución de la velocidad media por arte de pesca: arrastre de fondo con puertas (OTB), arrastre de fondo a la pareja (PTB), enmalle (GNS), palangre de fondo fijo (LLS), cerco (PS) y línea de mano (HLM). 

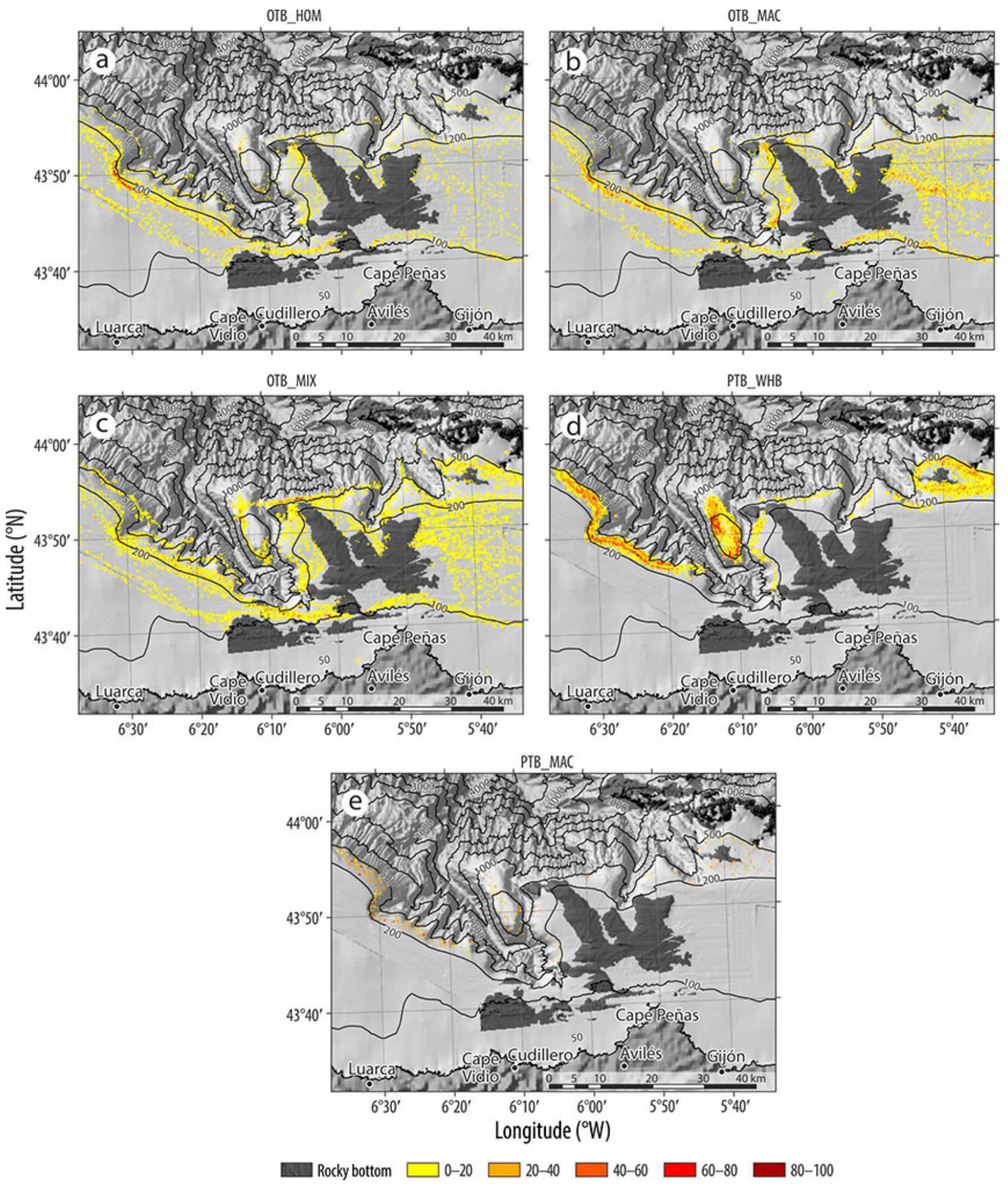

Figure S2. Spatial distribution of fisheries by fishing tactic for bottom otter trawl (OTB) and bottom pair trawl (PTB): (a) OTB_HOM, (b) OTB_MAC, (c) OTB_MIX, (d) PTB_WHB, and (e) PTB_MAC. Color scale indicates relative effort.

Figura 2. Distribución espacial de la actividad pesquera por táctica pesquera para el arrastre de fondo con puertas (OTB) y el arrastre de fondo a la pareja (PTB): (a) OTB_HOM, (b) OTB_MAC, (c) OTB_MIX, (d) PTB_WHB y (e) PTB_MAC. La escala muestra el esfuerzo relativo. 

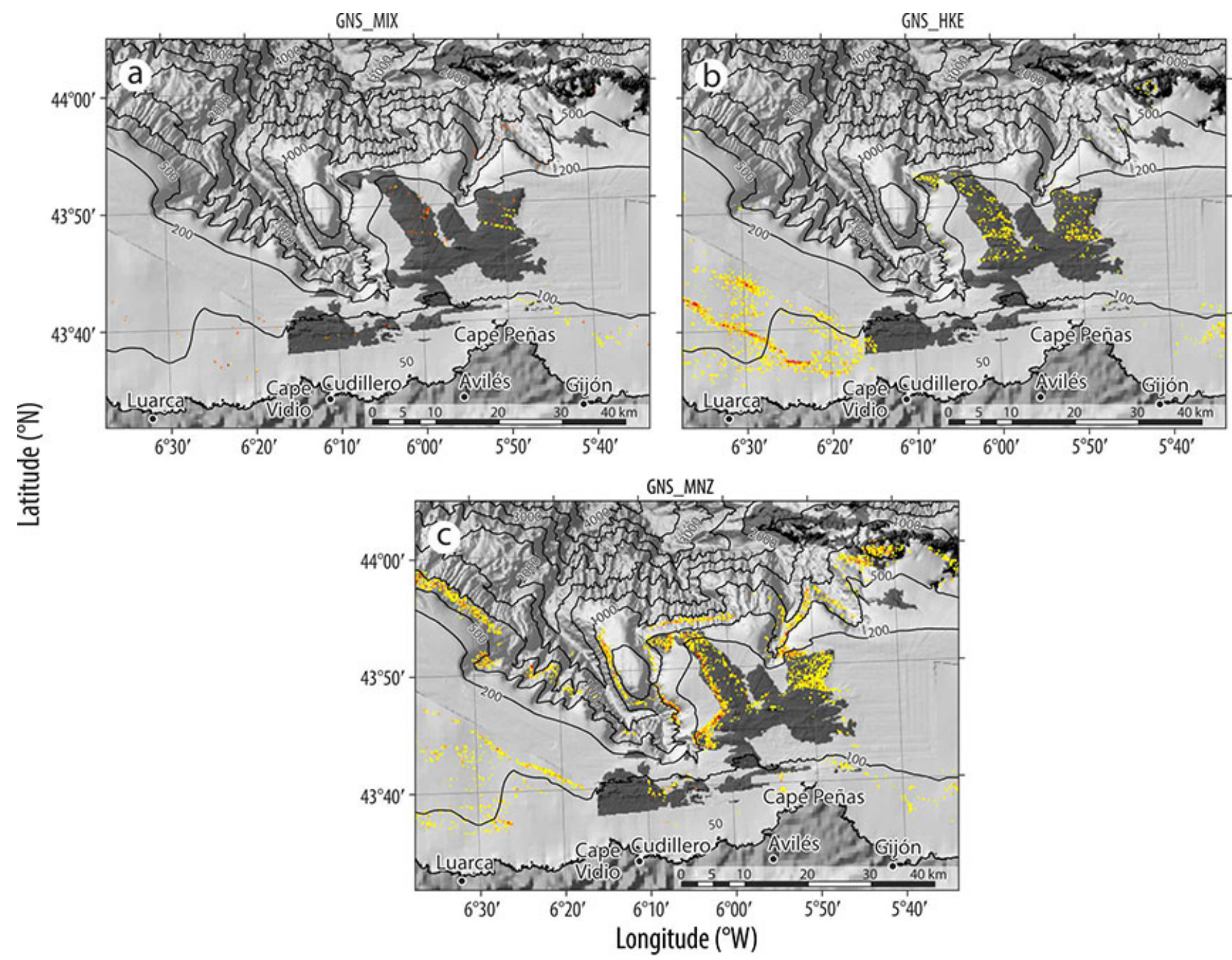

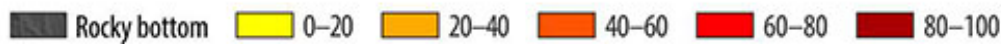

Figure S3. Spatial distribution of fisheries by fishing tactic for gillnet (GNS): (a) GNS_MIX, (b) GNS_HKE, and (c) GNS_MNZ. Color scale indicates relative effort. Color scale indicates relative effort.

Figura S3. Distribución espacial de las pesquerías por táctica pesquera para el enmalle (GNS): (a) GNS_MIX, (b) GNS_HKE y (c) GNS_MNZ. La escala muestra el esfuerzo relativo. 

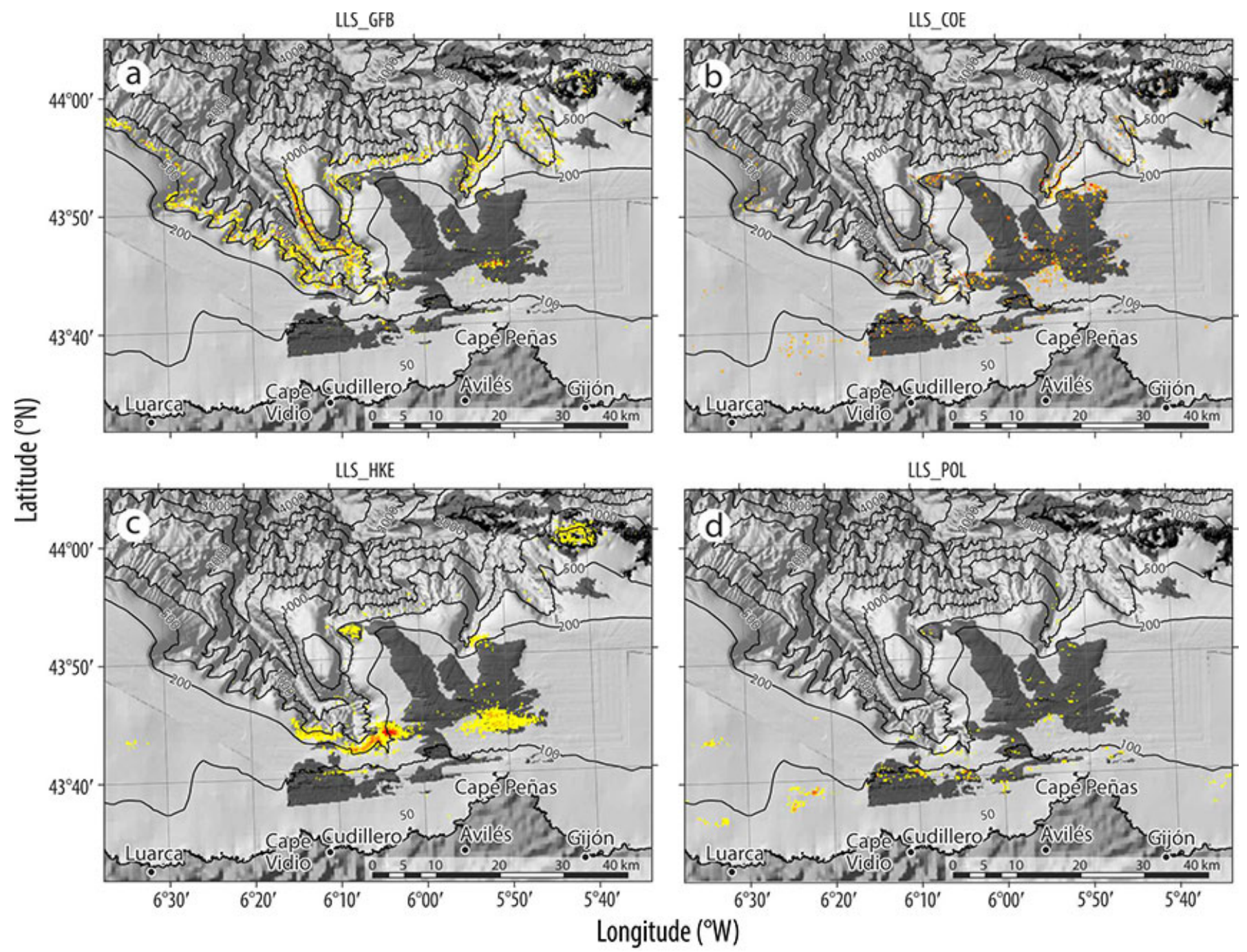

Rocky bottom

$0-20$

$20-40$

$40-60$

$60-80$

80-100

Figure S4. Spatial distribution of fisheries by fishing tactic for set longline (LLS): (a) LLS_GFB, (b) LLS_COE, (c) LLS_HKE, and (d) LLS_POL. Color scale indicates relative effort.

Figura S4. Distribución espacial de las pesquerías por táctica pesquera para el palangre de fondo fijo (LLS): (a) LLS_GFB, (b) LLS_COE, (c) LLS_HKE y (d) LLS_POL. La escala muestra el esfuerzo relativo. 

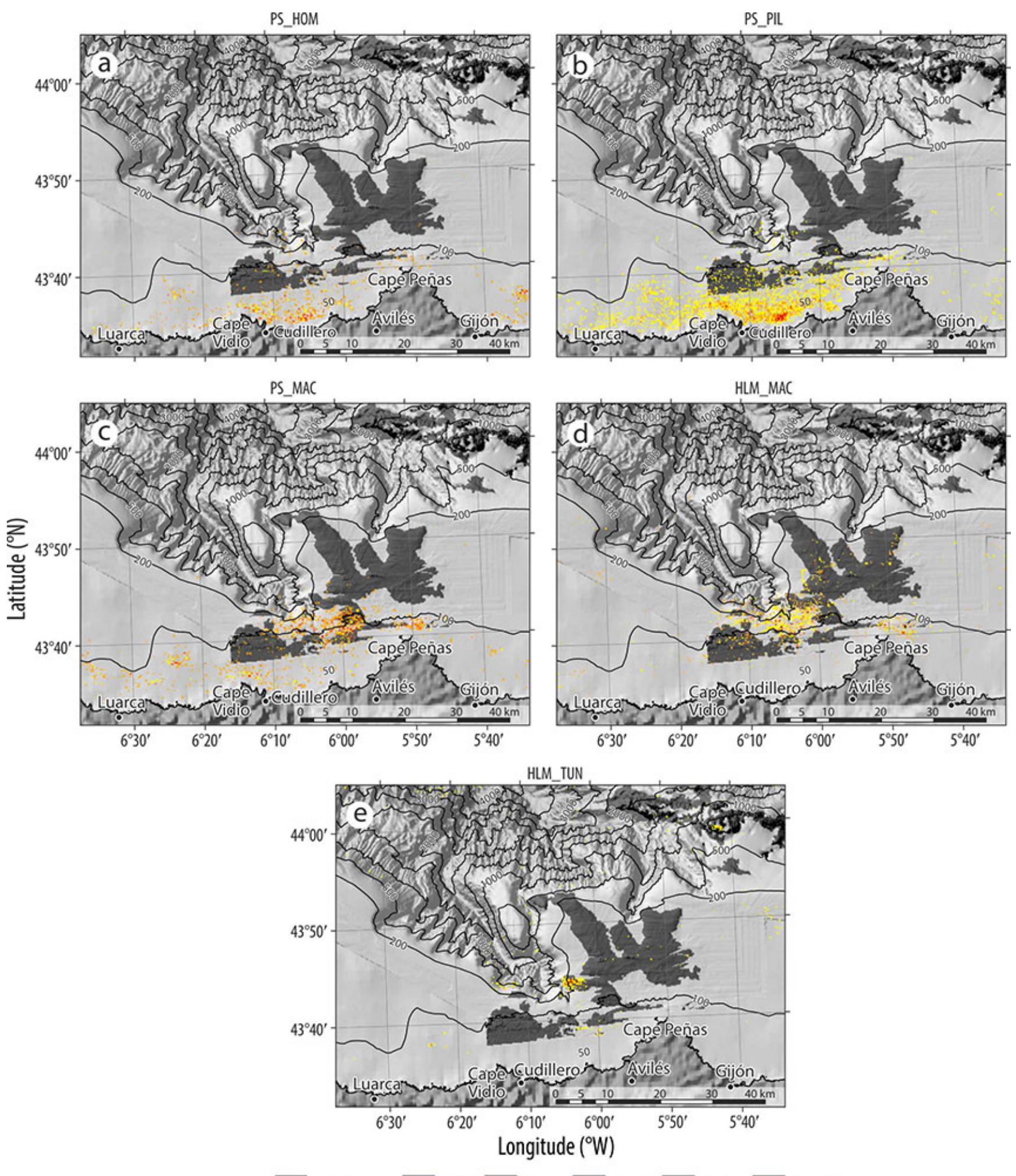

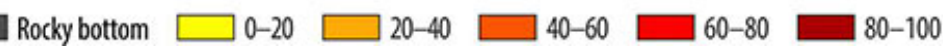

Figure S5. Spatial distribution of fisheries by fishing tactic for purse seine (PS) and handline (HLM): (a) PS_HOM, (b) PS_PIL, (c) PS_MAC, (d) HLM_MAC, and (e) HLM_TUN. Color scale indicates relative effort.

Figura S5. Distribución espacial de las pesquerías por táctica pesquera para el cerco (PS) y la línea de mano (HLM): (a) PS_HOM, (b) PS_PIL, (c) PS_MAC, (d) HLM_MAC, (e) HLM_TUN. La escala muestra el esfuerzo relativo. 